\title{
Die Zitate in der Originalsprache
}

Die Zitate sind in alphabetischer Reihenfolge nach den Nachnamen der Autor`innen angeordnet. Bei mehreren Zitaten desselben Autors oder derselben Autorin aus verschiedenen Werken oder Werkausgaben erfolgte die Anordnung in chronologischer Reihenfolge nach den Publikationsjahren der verwendeten Ausgaben, wobei mit den älteren Publikationen begonnen wurde. Bei mehreren Zitaten innerhalb einer Textausgabe richtet sich deren Abfolge nach den Seitenzahlen.

Abénon, Lucien-René: La Révolution aux Caraïbes. Antilles 1789. Paris: Nathan 1989, S. 61: Le fondement de cette nomenclature raciale était de prétendre souligner le plus «scientifiquement» possible que la marque du sang noir restait à jamais ineffaçable. Ainsi, les libres sont-ils nommés par les Blancs tantôt «sang-mêlés», tantôt «gens de couleur», tantôt «mulâtres» et, plus tard, serontils appelés «jaunes» par les Noirs de Saint-Domingue. Quant aux appellations de «métis» ou de «métive», elles sont réservées aux très rares descendants des Indiens. Aux îles du Vent on ne s'embarrasse de tant de subtilités : les libres sont généralement des «mulâtres».

Arenas, Reinaldo: Otra vez el mar. Barcelona: Editorial Argos Vergara 1982, S. 9: El mar. Azul. Al principio no. Al principio es más bien amarillo. Cenizo, diría... Aunque tampoco es cenizo. Blanco, quizás. Blanco no quiere decir transparente. Blanco. Pero luego, casi también al principio, se vuelve gris. Gris, por un rato. Y después, oscuro. Lleno de surcos todavía más oscuros. Rajaduras dentro del agua. Quizás sean las olas. O no: sólo espejismos del agua, y el sol. Si fueran olas llegarían a la costa. Es decir, a la arena. Pero no hay olas. Solamente, el agua. Que golpea, casi torpe, la tierra. Pero, no la golpea. Si la golpeara, se oiría algún ruido. Hay silencio. Solamente el agua, tocando la tierra. Sin golpearla. Llega, blanca, no transparente, la toca, torpemente, y se aleja. No es la tierra: es la arena. Cuando el agua sube, sin olas, la arena quizás suelte un ruido. Satisfecha. Desde aquí no oigo nada. El agua sube, pero no se ve bajar. La arena la absorbe. Por debajo vuelve al mar... Y, más allá, ya no es gris sino pardusco. Muy oscuro. Casi negro. Hasta que al fin, efectivamente, es negro. Pero ya es muy alto. Se une con el cielo. Los dos, por separados, no se pueden distinguir. Así que entonces, mirando fijamente, nunca es azul...

Balzac, Honoré de: Avant-propos. In (ders.): La Comédie humaine. Bd. I. Paris: Gallimard (Edition de la Pléiade) 1976, S. 11: En dressant l'inventaire des vices et des vertus, en rassemblant les principaux faits des passions, en peignant 
les caractères, en choisissant les événements principaux de la Société, en composant des types par la réunion des traits de plusieurs caractères homogènes, peut-être pouvais-je arriver à écrire l'histoire oubliée par tant d'historiens, celle des mœurs.

Balzac, Honoré de: Sarrasine. In (ders.): La Comédie humaine. Bd. VI. Etudes de Mours: Scènes de la vie parisienne. Edition publiée sous la direction de Pierre-Georges Castex avec, pour ce volume, la collaboration de Pierre Citron, René Guise, André Lorant et Anne-Marie Meininger. Paris: Gallimard (Bibliothèque de la Pléiade) 1977, S. 1052: Ce visage noir était anguleux et creusé dans tous les sens. Le menton était creux; les tempes étaient creuses; les yeux étaient perdus en de jaunâtres orbites. Les os maxillaires rendus saillants par une maigreur indescriptible, dessinaient des cavités au milieu de chaque joue. Ces gibbosités, plus ou moins éclairées, par les lumières, produisirent des ombres et des reflets curieux qui achevaient d'ôter à ce visage les caractères de la face humaine.

S. 1060: Sarrasine poussa des cris de plaisir. Il admirait en ce moment la beauté idéale de laquelle il avait jusqu'alors cherché çà et là les perfections dans la nature, en demandant à un modèle, souvent ignoble, les rondeurs d'une jambe accomplie; à tel autre, les contours du sein; à celui-là, ses blanches épaules; prenant enfin le cou d'une jeune fille, et les mains de cette femme, et les genoux polis de cet enfant, sans rencontrer jamais sous le ciel froid de Paris les riches et suaves créations de la Grèce antique. La Zambinella lui montrait réunies, bien vivantes et délicates, ces exquises proportions de la nature féminine si ardemment désirées, desquelles un sculpteur est, tout à la fois, le juge le plus sévère et le plus passionné.

S. 1062: Ce fut une sorte de méditation matérielle. Sur telle feuille, la Zambinella se trouvait dans cette attitude, calme et froide en apparence, affectionnée par Raphaël, par le Giorgion et par tous les grands peintres. Sur telle autre, elle tournait la tête avec finesse en achevant une roulade, et semblait s'écouter ellemême. Sarrasine crayonna sa maîtresse dans toutes les poses: il la fit sans voile, assise, debout, couchée, ou chaste ou amoureuse, en réalisant, grâce au délire de ses crayons, toutes les idées capricieuses qui sollicitent notre imagination quand nous pensons fortement à une maîtresse. Mais sa pensée furieuse alla plus loin que le dessin. Il voyait la Zambinella, lui parlait, la suppliait, épuisait mille années de vie et de bonheur avec elle, en la plaçant dans toutes les situations imaginables, en essayant, pour ainsi dire, l'avenir avec elle. 


\section{Balzac, Honoré de: La Peau de Chagrin. Introduction, notes et relevé de variantes par Maurice Allem. Edition illustrée. Paris: Editions Garnier 1985,}

S. 37: Je vais vous révéler en peu de mots un grand mystère de la vie humaine. L'homme s'épuise par deux actes instinctivement accomplis qui tarissent les sources de son existence. Deux verbes expriment toutes les formes que prennent ces deux causes de mort: VOULOIR ET POUVOIR. Entre ces deux termes de l'action humaine, il est une autre formule dont s'emparent les sages, et je lui dois le bonheur et ma longévité. Vouloir nous brûle, et pouvoir nous détruit; mais SAVOIR laisse notre faible organisation dans un perpétuel état de calme. Ainsi le désir ou le vouloir est mort en moi, tué par la pensée; le mouvement ou le pouvoir s'est résolu par le jeu naturel de mes organes. En deux mots, j'ai placé ma vie, non dans le coeur qui se brise, non dans les sens qui s'émoussent, mais dans le cerveau qui ne s'use pas et qui survit à tout.

S. 173 f.: Il suffit à un jeune homme de rencontrer une femme qui ne l'aime pas, ou une femme qui l'aime trop, pour que toute sa vie soit dérangée. Le bonheur engloutit nos forces, comme le malheur éteint nos vertus. Revenu à mon hôtel de Saint-Quentin, je contemplai longtemps la mansarde où j'avais mené la chaste vie d'un savant, une vie qui peut-être aurait été honorable, longue, et que je n'aurais pas dû quitter pour la vie passionnée qui m'entraînait dans un gouffre. Pauline me surprit dans une attitude mélancolique.

S. 193: Une horrible pâleur dessina tous les muscles de la figure flétrie de cet héritier, ses traits se contractèrent, les saillies de son visage blanchirent, les creux devinrent sombres, le masque fut livide, et les yeux se fixèrent. Il voyait la MORT. Ce banquier splendide entouré de courtisanes fanées, de visages rassasiés, cette agonie de la joie était une vivante image de sa vie. Raphaël regarda trois fois le talisman, qui jouait à l'aise dans les impitoyables lignes imprimées sur la serviette: il essayait de douter, mais un clair pressentiment anéantissait son incrédulité. Le monde lui appartenait, il pouvait tout et ne voulait plus rien. Comme un voyageur au milieu du désert, il avait un peu d'eau pour la soif et devait mesurer sa vie au nombre des gorgées. Il voyait ce que chaque désir devait lui coûter de jours. Puis il croyait à la peau de chagrin, il s'écoutait respirer, il se sentait déjà malade [...].

Barthes, Roland: Leçon. Leçon inaugurale de la Chaire de sémiologie littéraire du Collège de France, prononcée le 7 janvier 1977. Paris: Seuil 1978, S. 45 f.: Il est un âge où l'on enseigne ce que l'on sait; mais il en vient ensuite un autre où l'on enseigne ce que l'on ne sait pas: cela s'appelle chercher. Vient peut-être maintenant l'âge d'une autre expérience: celle de désapprendre, de laisser travailler le remaniement imprévisible que l'oubli impose à la sédimentation des savoirs, des cultures, des croyances que l'on a traversés. Cette expérience a, je crois, un nom 
illustre et démodé, que j'oserai prendre ici sans complexe, au carrefour même de son étymologie: Sapientia: nul pouvoir, un peu de savoir, un peu de sagesse, et le plus de saveur possible.

Baudelaire, Charles: Lettre à Desnoyers (1853/1854). In (Ders.): Hommage à C. F. Denecourt. Fontainebleau : paysages - légendes - souvenirs - fantaisies. Texte établi par (préface de Auguste Luchet). Paris: Librairie de L. Hachette et Cie 1855, S. 73f.: Mon cher Desnoyers, vous me demandez des vers pour votre petit volume, des vers sur la Nature, n'est-ce pas? sur les bois, les grands chênes, la verdure, les insectes, - le soleil, sans doute? Mais, vous savez bien que je suis incapable de m'attendrir sur les végétaux et que mon âme est rebelle à cette singulière religion nouvelle, qui aura toujours, ce me semble, pour tout être spirituel je ne sais quoi de shocking. Je ne croirai jamais que l'âme des Dieux habite dans les plantes, et quand-même elle y habiterait, je m'en soucierais médiocrement, et considérerais la mienne comme d'un bien plus haut prix que celle des légumes sanctifiés. J'ai même toujours pensé qu'il y avait dans la Nature, florissante et rajeunie, quelque chose d'imprudent et d'affligeant. Dans l'impossibilité de vous satisfaire complètement, suivant les termes stricts du programme, je vous envoie deux morceaux poétiques, qui représentent, à peu près, la somme des rêveries dont je suis assailli aux heures crépusculaires. Dans le fond des bois, enfermé sous ces voûtes semblables à celles des sacristies et des cathédrales, je pense à nos étonnantes villes, et la prodigieuse musique qui roule sur les sommets me semble la traduction des lamentations humaines.

Bécquer, Gustavo Adolfo: Rimas; Leyendas escogidas. Hg. Rubén Benítez. Madrid: Taurus 1990, S. 61-63: Por los tenebrosos rincones de mi cerebro, acurrucados y desnudos, duermen los extravagantes hijos de mi fantasía esperando en silencio que el Arte los vista de la palabra para poderse presentar decentes en la escena del mundo. [...] Y aquí dentro, desnudos y deformes, revueltos y barajados en indescriptible confusión, los siento a veces agitarse y vivir con una vida oscura y extraña, semejante a la de esas miríadas de gérmenes que hierven y se estremecen en una eterna incubación dentro de las entrañas de la tierra, sin encontrar fuerzas bastantes para salir a la superficie y convertirse, al beso del sol, en flores y frutos. Conmigo van, destinados a morir conmigo, sin que de ellos quede otro rastro que el que deja un sueño de medianoche que a la mañana no puede recordarse. En algunas ocasiones y ante esta idea terrible, se subleva en ellos el instinto de la vida y agitándose en terrible aunque silencioso tumulto, buscan en tropel por dónde salir a la luz, de las tinieblas en que viven. Pero jay! que entre el mundo de la idea y el de la forma existe un abismo que sólo puede salvar la palabra, y la palabra, tímida y perezosa, se niega a secundar sus esfuer- 
zos. Mudos, sombríos e impotentes, después de la inútil lucha vuelven a caer en su antiguo marasmo. ¡tal caen inertos en los surcos de las sendas, si cesa el viento, las hojas amarillas que levantó el remolino! [...] Deseo ocuparme un poco del mundo que me rodea pudiendo, una vez vacío, apartar los ojos de este otro mundo que llevo dentro de la cabeza. El sentido común que es la barrera de los sueños, comienza a flaquear y las gentes de diversos campos se mezclan y confunden. Me cuesta trabajo saber qué cosas he soñado y cuáles me han sucedido. Mis afectos se reparten entre fantasmas de la imaginación y personajes reales. Mi memoria clasifica, revueltos, nombres y fechas de mujeres y días que han muerto o han pasado con las de días y mujeres que no han existido sino en mi mente. Preciso es acabar arrojándolos de la cabeza de una vez para siempre.

\section{Béguin, Albert: L'âme romantique et le rêve. Essai sur le romantisme alle- mand et la poésie française. Nouvelle édition. Paris: Librairie José Corti 1939,}

S. 397 u. 401: Un vague remords avertit l'homme moderne qu'il a eu peut-être, qu'il pourrait avoir, avec le monde où il est placé, des rapports plus profonds et plus harmonieux. Il sait bien qu'il y a en lui-même des possibilités de bonheur ou de grandeur dont il s'est détourné. [...] L'idée de l'universelle analogie, à laquelle se réfère la conception romantique et moderne de la poésie, est la réponse de l'esprit humain à l'interrogation qu'il se pose, et l'expression de son vœu le plus profond. Il a souhaité d'échapper au temps et au monde des apparences multiples, pour saisir enfin l'absolu et l'unité. La chaîne des analogies lui apparaît, par instants, comme le lien qui, rattachant toute chose à toute autre chose, parcourt l'infini et établit l'indissoluble cohésion de l'Etre. Considéré de ce point de vue, le mythe du rêve prend une signification nouvelle. Le songe n'est plus seulement l'une des phases de notre vie, où nous nous retrouvons en communication avec la réalité profonde. Il est davantage même que le modèle précieux de la création esthétique, et on ne se contente plus de recueillir ses innombrables métaphores spontanées par quoi le génie onirique met en relation des moments séparés par le temps, des êtres et des objets distants dans l'espace. Le Rêve et la Nuit deviennent les symboles par lesquels un esprit, désireux de quitter les apparences pour rejoindre l'Etre, tente d'exprimer l'anéantissement du monde sensible.

Bolívar, Simón: Escritos políticos. Madrid: Alianza Editorial 1969, S. 19: No he dejado de ser educado como un niño de distinción puede ser en América bajo el poder español [...]. No es cierto que mi educación fue muy descuidada, puesto que mi madre y mis tutores hicieron cuanto era posible porque yo aprendiese; me buscaron maestros de primer orden en mi país. Robinson (Simón Rodríguez) fue mi maestro de primeras letras; de bellas letras y geografía, nuestro famoso Bello; se 
puso una academia de matemáticas sólo para mí por el padre Andújar, que estimó mucho el barón de Humboldt. Después me mandaron a Europa a continuar mis matemáticas en la Academia de San Fernando; y aprendía los idiomas extranjeros con maestros selectos de Madrid; todo bajo la dirección del sabio marqués de Uztaris en cuya casa vivía. Todavía muy niño, quizá sin poder aprender, se me dieron lecciones de esgrima, de baile y de equitación. Ciertamente que no aprendí ni la filosofía de Aristóteles, ni los códigos del crimen y del error; pero puede ser que Monsieur de Mollien no haya estudiado tanto como yo a Locke, Condillac, Buffon, Dalembert (sic!), Helvetius, Montesquieu, Mably, Filangieri, Lalande, Rousseau, Voltaire, Rollin, Berthot y todos los clásicos de la Antigüedad, así filósofos, historiadores, oradores y poetas; y todos los clásicos modernos de España, Francia, Italia y gran parte de los ingleses [...].

S. 47 u. 57: Libertar a la Nueva Granada de la suerte de Venezuela, y redimir a ésta de la que padece, son los objetos que me he propuesto en esta memoria. Dignaos, oh mis conciudadanos, de aceptarla con indulgencia en obsequio de miras tan laudables. Yo soy, granadinos, un hijo de la infeliz Caracas, escapado prodigiosamente de en medio de sus ruinas físicas, y políticas, que siempre fiel al sistema liberal, y justo que proclamó mi patria, he venido a seguir aquí los estandartes de la independencia, que tan gloriosamente tremolan en estos estados. [...] El honor de la Nueva Granada exige imperiosamente, escarmentar a esos osados invasores, persiguiéndoles hasta los últimos atrincheramientos, como su gloria depende de tomar a su cargo la empresa de marchar a Venezuela, a libertar la cuna de la independencia colombiana, sus mártires, y aquel benemérito pueblo caraqueño, cuyos clamores sólo se dirigen a sus amados compatriotas los granadinos, que ellos aguardan con una mortal impaciencia, como a sus redentores. Corramos a romper las cadenas de aquellas víctimas que gimen en las mazmorras, siempre esperando su salvación de vosotros: no burléis su confianza: no seáis insensibles a los lamentos de vuestros hermanos. Id veloces a vengar al muerto, a dar vida al moribundo, soltura al oprimido y libertad a todos. Cartagena de Indias, diciembre 15 de 1812.

S. 63: El suceso coronará nuestros esfuerzos porque el destino de la América se ha fijado irrevocablemente; el lazo que la unía a la España está cortado: la opinión era toda su fuerza; por ella se estrechaban mutuamente las partes de aquella inmensa monarquía; lo que antes las enlazaba, ya las divide; más grande es el odio que nos ha inspirado la Península, que el mar que nos separa de ella; menos difícil es unir los dos continentes, que reconciliar los espíritus de ambos países. [...] todo lo sufrimos de esa desnaturalizada madrastra. El velo se ha rasgado, ya hemos visto la luz, y se nos quiere volver a las tinieblas; se han roto las cadenas; ya hemos sido libres, y nuestros enemigos pretenden de nuevo esclavizarnos. 
S. 69 f.: Todavía es más difícil presentir la suerte futura del Nuevo Mundo, establecer principios sobre su política, y casi profetizar la naturaleza del gobierno que llegará a adoptar. Toda idea relativa al porvenir de este país me parece aventurada. ¿Se pudo prever cuando el género humano se hallaba en su infancia, rodeado de tanta incertidumbre, ignorancia y error, cuál sería el régimen que abrazaría para su conservación? ¿Quién se habría atrevido a decir tal nación será república o monarquía, ésta será pequeña, aquélla grande? En mi concepto, esta es la imagen de nuestra situación. Nosotros somos un pequeño género humano; poseemos un mundo aparte; cercado por dilatados mares, nuevo en casi todas las artes y ciencias, aunque en cierto modo viejo en los usos de la sociedad civil. Yo considero el estado actual de la América como cuando desplomado el Imperio Romano cada desmembración formó un sistema político, conforme a sus intereses y situación o siguiendo la ambición particular de algunos jefes, familias o corporaciones; con esta notable diferencia, que aquellos miembros dispersos volvían a restablecer sus antiguas naciones con las alteraciones que exigían las cosas o los sucesos; mas nosotros, que apenas conservamos vestigios de lo que en otro tiempo fue, y que por otra parte no somos indios ni europeos, sino una especie media entre los legítimos propietarios del país y los usurpadores españoles: en suma, siendo nosotros americanos por nacimiento y nuestros derechos los de Europa, tenemos que disputar éstos a los del país y que mantenernos en él contra la invasión de los invasores; así nos hallamos en el caso más extraordinario y complicado; no obstante que es una especie de adivinación indicar cuál será el resultado de la línea de política que la América siga, me atrevo a aventurar algunas conjeturas, que, desde luego, caracterizo de arbitrarias, dictadas por un deseo racional, y no por un raciocinio probable.

S. 81: Es una idea grandiosa pretender formar de todo el Mundo Nuevo una sola nación con un solo vínculo que ligue sus partes entre sí y con el todo. Ya que tiene un origen, una lengua, unas costumbres y una religión debería, por consiguiente, tener un solo gobierno que confederase los diferentes estados que hayan de formarse; mas no es posible, porque climas remotos, situaciones diversas, intereses opuestos, caracteres desemejantes dividen a la América. ¡Qué bello sería que el istmo de Panamá fuese para nosotros lo que el de Corinto para los griegos! Ojalá que algún día tengamos la fortuna de instalar allí un augusto congreso de los representantes de las repúblicas, reinos o imperios a tratar y discutir sobre los altos intereses de la paz y de la guerra con las naciones de las otras tres partes del mundo. Esta especie de corporación podrá tener lugar en alguna época dichosa de nuestra regeneración [...].

S. 83: Felizmente los directores de la independencia de Méjico se han aprovechado del fanatismo con el mejor acierto, proclamando a la famosa virgen de Guadalupe por reina de los patriotas; invocándola en todos los casos arduos y lle- 
vándola en sus banderas. Con esto el entusiasmo político ha formado una mezcla con la religión, que ha producido un fervor vehemente por la sagrada causa de la libertad. La veneración de esta imagen en Méjico es superior a la más exaltada que pudiera inspirar el más diestro profeta.

S. 84: Luego que seamos fuertes, bajo los auspicios de una nación liberal que nos preste su protección, se nos verá de acuerdo cultivar las virtudes y los talentos que conducen a la gloria; entonces seguiremos la marcha majestuosa hacia las grandes prosperidades a que está destinada la América meridional; entonces las ciencias y las artes, que nacieron en el Oriente y han ilustrado la Europa, volarán a Colombia libre, que las convidará con un asilo.

Bolívar, Simón: Carta de Bolívar al general Juan José Flores (1830), zitiert nach González Paredes, Ramón: Simón Bolívar, la angustia del sueño. Caracas: Tecnodidacta 1982, S. 662: Primero: la America es ingobernable para nosotros. Segundo: el que sirve una revolución ara en el mar. Tercero: la única cosa que se puede hacer en América es emigrar. Cuarta: este país caerá infaliblemente en manos de la multitud desencenada para después pasar a tiranuelos casi imperceptibles de todos los colores y razas. Quinto: devorado por todos los crímenes y extinguidos por la ferocidad, los europeos no se dignarán conquistarnods. Sexto: si fuera posible que una parte del mundo volviera al caos primitivo, este sería el último período de la América.

Borrero, Juana: Epistolario. 2 Bde. La Habana: Academia de Ciencias de Cuba 1966-1967, hier Bd. II, S. 257 (Interpunktion und Schreibweise im Original): De un modo $u$ otro, la Patria ¿no es una rival como otra cualquiera? Y rival dichosa porque me sacrificas a ella! ¿ Te parece vergonzoso no acudir a su reclamo... y no te parece criminal hundir de un solo golpe todas las esperanzas de un alma como la mía? Si no te conmueven mis lágrimas y si la certeza de mi muerte no te deciden, de qué tienes el corazón? [...] Tu patria. o tu Juana: elige. Si te vas me pierdes.

Cambaceres, Eugenio: Sin rumbo (Estudio). Estudio preliminar y Edición crítica de Rita Gnutzmann. Blibao: Servicio Editorial de la Universidad del País Vasco 1993, S. 51: ¡La universidad, pensaba Andrés, época feliz, haragán, estudiante y rico! El Club, el mundo, los placeres, la savia de la pubertad arrojada a manos llenas, perdidos los buenos tiempos, árido por falta de cultivo y de labor, baldío, seco el espíritu que tiene en la vida, se decía, como las hembras en el año, su primavera de fecundación y de brama. Después, joh! después es inútil, imposible; es la rama de sauce enterrada cuando ya calienta el sol. Vanos los esfuerzos, la reacción intentada, los proyectos, los cambios vislumbrados a la luz de la 
razón, pasajero rayo de sol entre dos nubes. Vanos los propósitos de enmienda, el estudio del derecho un instante abrazado con calor y abandonado luego bajo el golpe de maza del fastidio. El repentino entusiasmo por la carrera del médico, la camaradería con los estudiantes pobres de San Telmo, el amor al anfiteatro, muerto de asco en la primera autopsia. Vanos más tarde las veleidades artísticas, las fugaces aspiraciones a lo grande y a lo bello, las escuelas de Roma y de París, el Vaticano, el Louvre, los Oficios, los talleres de los maestros Meissonier, Monteverde, Madrazo, Carrier-Beleuse, entrevistos y dejados por otra escuela mejor: el juego y las mujeres; la orgía.

S. 95: Era una sala cuadrada grande, de un lujo fantástico, opulento, un lujo a la vez de mundano refinado y de artista caprichoso. El pie se hundía en una espesa alfombra de Esmirna. Alrededor, contra las paredes, cubiertas de arriba abajo por viejas tapicerías de seda de la China, varios divanes se veían de un antiguo tejido turco. Hacia el medio de la pieza, en mármol de Carrara, un grupo de Júpiter y Leda de tamaño natural. Acá y allá, sobre pies de ónix, otros mármoles, reproducciones de bronces obscenos de Pompeya, almohadones orientales arrojados al azar, sin orden por el suelo, mientras en una alcoba contigua, bajo los pesados pliegues de un cortinado de lampas vieil or, la cama se perdía, una cama colchada de raso negro, ancha, baja, blanda. Al lado, el cuarto de baño al que una puerta secreta practicada junto a la alcoba conducía, era tapizado de negro todo, como para que resaltara más la blancura de la piel.

S. 99: Nada en el mundo le halagaba ya, le sonreía; decididamente nada lo vinculaba a la tierra. Ni ambición, ni poder, ni gloria, ni hogar, ni amor, nada le importaba, nada quería, nada poseía, nada sentía. En su ardor, en su loco afán por apurar los goces terrenales, todos los secretos resortes de su ser se habían gastado como se gasta una máquina que tiene de continuo sus fuegos encendidos. Desalentado, rendido, postrado andaba al azar, sin rumbo, en la noche negra y helada de su vida... Pero, entonces, ¿por qué andar; por qué vivir? Y la idea del suicidio, como una puerta que se abre de pronto entre tinieblas, atrayente, tentadora, por primera vez cruzó su mente enferma.

S. 144 f.: Pensaba en la triste condición de la mujer, marcada al nacer por el dedo de la fatalidad, débil de espíritu y de cuerpo, inferior al hombre en la escala de los seres, dominada por él, relegada por la esencia misma de su naturaleza al segundo plan de la existencia. [...] La limitación estrecha de sus facultades, los escasos alcances de su inteligencia incapaz de penetrar en el dominio profundo de la ciencia, rebelde a las concepciones sublimes de las artes, la pobreza de su ser moral, refractario a todas las altas nociones de justicia y de deber, el aspecto mismo de su cuerpo, su falta de nervio y de vigor, la molicie de sus formas, la delicadeza de sus líneas, la suavidad de su piel, la morbidez de su carne ¿no revelaban claramente su destino, la misión que la naturaleza le había dado, no 
estaban diciendo a gritos que era un ser consagrado al amor esencialmente, casi un simple instrumento de placer, creado en vista de la propagación sucesiva y creciente de la especie? ¡Ah! ¡cuánto más sensatos y más sabios eran los pueblos del Oriente, cuanto mejor, más llevadera la suerte de la mujer bajo esas leyes, traducción fiel de las leyes naturales!

S. 172: Andrés, él, nada vio, ni un músculo de su rostro se contrajo en presencia de aquella escena de ruina y destrucción. Imperturbable, siguió andando, llegó hasta descolgar de la pared un cuchillo de caza, un objeto de precio, una obra de arte que, junto con otras armas antiguas, tenía allí, en una panoplia. Volvió, se sentó, se desprendió la ropa, se alzó la falda de la camisa, y tranquilamente, reflexivamente, sin fluctuar, sin pestañear, se abrió la barriga en cruz, de abajo arriba y de un lado a otro, toda... Pero los segundos, los minutos se sucedían y la muerte asimismo no llegaba. Parecía mirar con asco esa otra presa, harta, satisfecha de su presa. Entonces, con rabia, arrojando el arma: - ¡Vida perra, puta...- rugió Andrés- yo te he de arrancar de cuajo!... Y recogiéndose las tripas y envolviéndoselas en torno de las manos, violentamente, como quien rompe una piola pegó un tirón. Un chorro de sangre y de excrementos saltó, le ensució la cara, la ropa, fue a salpicar sobre la cama el cadáver de su hija, mientras él, boqueando, rodaba por el suelo...

Cánovas del Castillo: Discurso pronunciado el día 26 de noviembre de 1870. Zit nach Litvak, Lily: España 1900, S. 160: Por donde quiera que hoy se mire sobran razones para envidiar a la raza germánica y para que doble humillada la cabeza toda la gente latina. Inferior anteriormente en la organización social y en las ciencias, eran dos últimos baluartes de su grandeza la Roma pontifical y el ejército francés, y las catástrofes simultáneas que hemos presenciado ponen el sello a una decadencia quizás de toda suerte inevitable.

Cansinos Assens, Rafael: Renacimiento latino, zitiert nach Litvak, Lily: España 1900, S. 175: Y todos unidos lucharemos con la antigua espada latina, que ahora vuelve a fulgurar y a herir, contra la invasión sajona, que quiere hacer una tierra brumosa y triste de esta tierra de sol. La raza latina renace fuerte de su sueño, como gladiador. Los hermanos se unen. Los hermanos son águilas, leones y el dragón oriental. Y con rugidos y aletazos, como en un canto apocalíptico, quieren hacer saber al mundo que la raza latina vive y es victoriosa aún.

\section{Carpentier, Alejo: El Siglo de las Luces. Barcelona: Editorial Seix Barral 1981,}

86 f.: Eran interesantes, insólitas, extraordinarias, ciertamente. Pero ninguna tan considerable, tan sensacional como la que se refería a la fuga del Rey y a su arresto en Varennes. Era algo tan tremendo, tan novedoso para cualquier mente, que las 
palabras «Rey» $\mathrm{y}$ «arresto» no acababan de acoplarse, de constituir una posibilidad inmediatamente admisible. ¡Un monarca arrestado, avergonzado, humillado, entregado a la custodia del pueblo a quien pretendía gobernar, cuando era indigno de hacerlo! La más grande corona, el más insigne poder, el más alto cetro del universo, traídos entre dos gendarmes. «Y yo, que estaba negociando con sederías de contrabando, cuando tales cosas pasaban en el mundo -decía Víctor, llevándose las manos a la cabeza-. Se estaba asistiendo, allá, al nacimiento de una nueva humanidad...» El Borée, impulsado por la brisa nocturna, bogaba despacio, bajo el cielo de estrellas tan claras que las montañas del Este se pintaban en tinieblas intrusas, cortando el puro dibujo de las constelaciones. Atrás quedaban los incendios de un día. Hacia el Oriente se erguía, enhiesta y magnífica, vislumbrada por los ojos del entendimiento, la Columna de Fuego que guía las marchas hacia toda Tierra Prometida.

S. 253: «Esta vez la revolución ha fracasado. Acaso la próxima sea la buena. Pero, para agarrarme cuando estalle, tendrán que buscarme con linternas a mediodía. Cuidémonos de las palabras hermosas; de los Mundos Mejores creados por las palabras. Nuestra época sucumbe por un exceso de palabras. No hay más Tierra Prometida que la que el hombre puede encontrar en sí mismo.» Y al decir esto pensaba Esteban en Ogé, que tan a menudo citaba una frase de su maestro Martínez de Pasqually: El ser humano sólo podrá ser iluminado mediante el desarrollo de las facultades divinas dormidas en él por el predominio de la materia...

S. 344 f.: Su verdadera entrada en la Historia data de la noche en que aquel establecimiento fue incendiado por los revolucionarios haitianos. A partir de ese momento, podemos seguir su trayectoria paso a paso, tal como se narra en este libro. Los capítulos consagrados a la conquista de la Guadalupe se guían por un esquema cronológico preciso. Cuanto se dice acerca de su guerra librada a los Estados Unidos -la que llamaron los yanquis de entonces «Guerra de Brigantes»- así como a la acción de los corsarios, con sus nombres y los nombres de sus barcos, está basado en documentos reunidos por el autor en la Guadalupe y en bibliotecas de la Barbados, así como en cortas pero instructivas referencias halladas en obras de autores latinoamericanos que, de paso, mencionaron a Víctor Hugues. [...] nos ofrece la imagen de un personaje extraordinario que establece, en su propio comportamiento, una dramática dicotomía. De ahí que el autor haya creído interesante revelar la existencia de ese ignorado personaje histórico en una novela que abarcara, a la vez, todo el ámbito del Caribe.

\section{Carpentier, Alejo: El reino de este mundo. Introducción Federico Acevedo.}

San Juan PR: EDUPR 1994, S. 8: [...] América está muy lejos de haber agotado su caudal de mitologías. Sin habérmelo propuesto de modo sistemático, el texto que sigue ha respondido a este orden de preocupaciones. En él se narra una 
sucesión de hechos extraordinarios, ocurridos en la isla de Santo Domingo, en determinada época que no alcanza el lapso de una vida humana, dejándose que lo maravilloso fluya libremente de una realidad estrictamente seguida en todos sus detalles. Porque es menester advertir que el relato que va a leerse ha sido establecido sobre una documentación extremadamente rigurosa que no solamente respeta la verdad histórica de los acontecimientos, los nombres de personajes -incluso secundarios-, de lugares y hasta de calles, sino que oculta, bajo su aparente intemporalidad, un minucioso cotejo de fechas y de cronologías. Y sin embargo, por la dramática singularidad de los acontecimientos, por la fantástica apostura de los personajes que se encontraron, en determinado momento, en la encrucijada mágica de la Ciudad del Cabo, todo resulta maravilloso en una historia imposible de situar en Europa, y que es tan real, sin embargo, como cualquier suceso ejemplar de los consignados, para pedagógica edificación, en los manuales escolares. ¿Pero qué es la historia de América toda sino una crónica de lo real-maravilloso?

S. 39 f.: De pronto, todos los abanicos se cerraron a un tiempo. Hubo un gran silencio detrás de las cajas militares. Con la cintura ceñida por un calzón rayado, cubierto de cuerdas y de nudos, lustroso de lastimaduras frescas, Mackandal avanzaba hacia el centro de la plaza. Los amos interrogaron las caras de sus esclavos con la mirada. Pero los negros mostraban una despechante indiferencia. ¿Qué sabían los blancos de cosas de negros? En sus ciclos de metamorfosis, Mackandal se había adentrado muchas veces en el mundo arcano de los insectos, desquitándose de la falta de un brazo humano con la posesión de varias patas, de cuatro élitros o de largas antenas. Había sido mosca, ciempiés, falena, comején, tarántula, vaquita de San Antón y hasta cocuyo de grandes luces verdes. En el momento decisivo, las ataduras del mandinga, privadas de un cuerpo que atar, dibujarían por un segundo el contorno de un hombre de aire, antes de resbalar a lo largo del poste. Y Mackandal, transformado en mosquito zumbón, iría a posarse en el mismo tricornio del jefe de las tropas, para gozar del desconcierto de los blancos. Eso era lo que ignoraban los amos; por ello habían despilfarrado tanto dinero en organizar aquel espectáculo inútil que revelaría sus total impotencia para luchar contra un hombre hundido por los grandes Loas. Mackandal estaba ya adosado al poste de torturas. El verdugo había agarrado un rescoldo con las tenazas. Repitiendo un gesto estudiado la víspera frente al espejo, el gobernador desenvainó su espada de corte y dio orden de que se cumpliera la sentencia. El fuego comenzó a subir hacia el manco, sollamándole las piernas. En ese momento, Mackandal agitó su muñón que no habían podido atar, en un gesto conminatorio que no por menguado era menos terrible, aullando conjuros desconocidos y echando violentamente el torso hacia adelante. Sus ataduras cayeron, y el cuerpo del negro se espigó en el aire, volando por sobre las cabezas, antes de hundirse en las ondas 
negras de la masa de esclavos. Un solo grito llenó la plaza. - Mackandal sauvé! Y fue la confusión y el estruendo.

S. 135f.: Ti Noel subió sobre su mesa, castigando la marquetería con sus pies callosos. Hacia la ciudad del Cabo el cielo se había vuelto de un negro de humo de incendios, como la noche en que habían cantado todos los caracoles de la montaña y de la costa. El anciano lanzó su declaración de guerra a los nuevos amos, dando orden a sus súbditos de partir al asalto de las obras insolentes de los mulatos investidos. En aquel momento, un gran viento verde surgido del Océano y cayó sobre la Llanura del Norte colándose por el valle del Dondón con un bramido inmenso. Ya en tanto que mugían toros degollados en lo alto del Gorro del Obispo, la butaca, el biombo, los tomos de la enciclopedia, la caja de música, la muñeca, el pez luna echaron a volar de golpe, en el derrumbe de las últimas ruinas de la antigua hacienda. Todos los árboles se acostaron de copa al sur, sacando las raíces de la tierra. Y durante toda la noche, el mar, hecho lluvia, dejó rastros de sal en los flancos de las montañas. Y desde aquella hora nadie supo más de Ti Noel ni de su casaca verde con puños de encaje salmón, salvo, tal vez, aquel buitre mojado, aprovechado de toda muerte, que esperó el sol con las alas abiertas: cruz de plumas que acabó por plegarse y hundir el vuelo en las espesuras de Bois Caimán.

Cervantes Saavedra, Miguel de: El ingenioso hidalgo Don Quijote de la Mancha. Primera parte. Leipzig: Brockhaus 1866, Capitulo IX, S. 39: Cuando yo oí decir "Dulcinea del Toboso", quedé atónito y suspenso, porque luego se me representó que aquellos cartapacios contenían la historia de Don Quijote. Con esta imaginación, le di prisa que leyese el principio, y, haciéndolo ansí, volviendo de improviso al arábigo en castellano, dijo que decía: "Historia de Don Quijote de la Mancha, escrita por Cide Hamete Benengeli, historiador arábigo." Mucha discreción fue menester para disimular el contento que recibí cuando llegó a mis oídos el título del libro [...].

\section{Chamisso, Adelbert von: Leben und Briefe. Herausgegeben von Julius Eduard Hitzig. Leipzig: Weidmann'sche Buchhandlung 1942, S. 271: Ma patrie. Je suis} français en Allemagne, et allemand en France, catholique chez les protestants, protestant chez les catholiques, philosophe chez les gens religieux et cagot chez les gens sans préjugés; homme du monde chez les savants, et pédant dans le monde, jacobin chez les aristocrates, et chez les démocrates un noble, un homme de l'Ancien Régime, etc. Je ne suis nulle part de mise, je suis partout étranger - je voudrais trop étreindre, tout m'échappe. Je suis malheureux - - - Puisque ce soir la place n'est pas encore prise, permettez-moi d'aller me jeter la tête première dans la rivière... 


\section{Chateaubriand, François-René vicomte de: Atala; René; Les Abencérages;} Suivies de Voyage en Amérique. Paris: Librairie de Firmin Didot frères 1871, Atala, S. 19f.: La France possédait autrefois, dans l'Amérique septentrionale, un vaste empire qui s'étendait depuis le Labrador jusqu'aux Florides, et depuis les rivages de l'Atlantique jusqu'aux lacs les plus reculés du haut Canada. Quatre grands fleuves, ayant leurs sources dans les mêmes montagnes, divisaient ces régions immenses [...]. Ce dernier fleuve, dans un cours de plus de mille lieues, arrose une délicieuse contrée que les habitants des Etats-Unis appellent le nouvel Eden, et à laquelle les Français ont laissé le doux nom de Louisiane.

S. 30: Une nuit que les Muscogulges avaient placé leur camp sur le bord d'une forêt, j'étais assis auprès du feu de la guerre, avec le chasseur commis à ma garde. Tout à coup j'entendis le murmure d'un vêtement sur l'herbe, et une femme à demi voilée vint s'asseoir à mes côtés. Des pleurs roulaient sur sa paupière ; à la lueur du feu un petit crucifix d'or brillait sur son sein. Elle était régulièrement belle ; l'on remarquait sur son visage je ne sais quoi de vertueux et de passionné, dont l'attrait était irrésistible. Elle joignait à cela des grâces plus tendres ; une extrême sensibilité, unie à une mélancolie profonde, respirait dans ses regards ; son sourire était céleste. Je crus que c'était la Vierge des dernières amours, cette vierge qu'on envoie au prisonnier de guerre, pour enchanter sa tombe.

S. 61 f.: C'en était trop pour nos cœurs que cette amitié fraternelle qui venait nous visiter, et joindre son amour à notre amour. Désormais les combats d'Atala allaient devenir inutiles : en vain je la sentis porter une main à son sein, et faire un mouvement extraordinaire ; déjà je l'avais saisie, déjà je m'étais enivré de son souffle, déjà j'avais bu toute la magie de l'amour sur ses lèvres. Les yeux levés vers le ciel, à la lueur des éclairs, je tenais mon épouse dans mes bras, en présence de l'Eternel. Pompe nuptiale, digne de nos malheurs et de la grandeur de nos amours: superbes forêts qui agitiez vos lianes et vos dômes comme les rideaux et le ciel de notre couche, pins embrasés qui formiez les flambeaux de notre hymen, fleuve débordé, montagnes mugissantes, affreuse et sublime nature, n'étiez-vous donc qu'un appareil préparé pour nous tromper, et ne pûtes-vous cacher un moment dans vos mystérieuses horreurs la félicité d'un homme! Atala n'offrait plus qu'une faible résistance ; je touchais au moment du bonheur, quand tout à coup un impétueux éclair, suivi d'un éclat de la foudre, sillonne l'épaisseur des ombres, remplit la forêt de soufre et de lumière, et brise un arbre à nos pieds. Nous fuyons. O surprise!... dans le silence qui succède, nous entendons le son d'une cloche ! Tous deux interdits, nous prêtons l'oreille à ce bruit, si étrange dans un désert. A l'instant un chien aboie dans le lointain ; il approche, il redouble ses cris, il arrive, il hurle de joie à nos pieds ; un vieux Solitaire portant une petite lanterne, le suit à travers les ténèbres de la forêt. «La Providence soit bénie ! s'écria-t-il, aussitôt qu'il nous aperçut. Il y a bien longtemps que je vous cherche !» 
S. 94-98: A peine a-t-il prononcé ces mots, qu'une force surnaturelle me contraint de tomber à genoux, et m'incline la tête au pied du lit d'Atala. Le prêtre ouvre un lieu secret où était renfermée une urne d'or, couverte d'un voile de soie ; il se prosterne et adore profondément. La grotte parut soudain illuminée ; on entendit dans les airs les paroles des anges et les frémissements des harpes célestes ; et lorsque le Solitaire tira le vase sacré de son tabernacle, je crus voir Dieu lui-même sortir du flanc de la montagne. Le prêtre ouvrit le calice ; il prit entre ses deux doigts une hostie blanche comme la neige, et s'approcha d'Atala, en prononçant des mots mystérieux. Cette sainte avait les yeux levés au ciel, en extase. Toutes ses douleurs parurent suspendues, toute sa vie se rassembla sur sa bouche ; ses lèvres s'entr'ouvrirent et vinrent avec respect chercher le Dieu caché sous le pain mystique. Ensuite le divin vieillard trempe un peu de coton dans une huile consacrée et l'en frotte les tempes d'Atala, il regarde un moment la fille mourante, et tout à coup ses fortes paroles lui échappent : «Partez, âme chrétienne : allez rejoindre votre Créateur !» Relevant alors ma tête abattue, je m'écriai en regardant le vase où était l'huile sainte : «Mon père, ce remède rendra-t-il la vie à Atala?» «Oui, mon fils, dit le vieillard en tombant dans mes bras, la vie éternelle !» Atala venait d'expirer ! [...] Ses lèvres, comme un bouton de rose, cueillie depuis deux matins, semblaient languir et sourire. Dans ses joues d'une blancheur éclatante, on distinguait quelques veines bleues. Ses beaux yeux étaient fermés, ses pieds modestes étaient joints, et ses mains d'albâtre pressaient sur son cœur un crucifix d'ébène ; le scapulaire de ses vœux était passé à son cou. Elle paraissait enchantée par l'Ange de la mélancolie, et par le double sommeil de l'innocence et de la tombe. Je n'ai rien vu de plus céleste. Quiconque eût ignoré que cette jeune fille avait joui de la lumière, aurait pu la prendre pour la statue de la Virginité endormie.

\section{Chimalpahin Quauhtlehuanitzin, Domingo Francisco de San Antón Muñón; zitiert nach Mignolo, Walter: Zur Frage der Schriftlichkeit in der Legiti- mation der Conquista. In: Kohut, Karl et al. (Hg.): Der eroberte Kontinent.} Frankfurt am Main: Vervuert 1991, S. 87: Entonces, el papel pintado y la historia de los linajes antiguos fueron dejados a su querido hijo el señor don Domingo Hernández Ayopochtzin, quien se instruyó en la ciencia de la cuenta de los libros y pintó un libro escribiéndolo con letras sin añadirle nada, sino como un fiel espejo de las cosas que de allí trasladó. Nuevamente ahora yo he pintado, he escrito con letras un libro en donde he dado cabida a todas las viejas historias.

Darío, Rubén: El rey burgués. In: ders.: Obras completas. Bd. V: Poesía. Madrid: Afrodisio Aguado 1953, S. 626 f.: El rey tenía un palacio soberbio donde había acumulado riquezas y objetos de arte maravillosos. Llegaba a él por entre 
grupos de lilas y extensos estanques, siendo saludado por los cisnes de cuellos blancos, antes que por los lacayos estirados. Buen gusto. Subía por una escalera llena de columnas de alabastro y de esmaragdita, que tenía a los lados leones de mármol como los de los tronos salomónicos. Refinamiento. A más de los cisnes, tenía una vasta pajarera, como amante de la armonía, del arrullo, del trino y cerca de ella iba a ensanchar su espíritu, leyendo novelas de M. Ohnet, o bellos libros sobre cuestiones gramaticales, o críticas hermosillescas. Eso sí: defensor acérrimo de la corrección académica en letras, y del modo lamido en artes, alma sublime amante de la lija y de la ortografía! [...] Por lo demás, había el salón griego, lleno de mármoles: diosas, musas, ninfas y sátiros; el salón de los tiempos galanes, con cuadros del gran Watteau y de Chardin; dos, tres, cuatro, ¡cuántos salones! Y Mecenas se paseaba por todos, con la cara inundada de cierta majestad, el vientre feliz y la corona en la cabeza, como un rey de naipe.'

\section{Echeverría, Esteban: El Matadero. La Cautiva. Edición de Leonor Fleming.} Madrid: Ediciones Cátedra 1986, S. 317 f.: Por un lado dos muchachos se adiestraban en el manejo del cuchillo tirándose horrendos tajos y reveses; por otro, cuatro ya adolescentes, ventilaban a cuchilladas el derecho a una tripa gorda y un mondongo que habían robado a un carnicero; y no de ellos distante, porción de perros flacos ya de la forzosa abstinencia, empleaban el mismo medio para saber quién se llevaría un hígado envuelto en barro. Simulacro en pequeño era éste del modo bárbaro con que se ventilaban en nuestro país las cuestiones y los derechos individuales y sociales. En fin: la escena que se representaba en el matadero era para vista, no para escrita.

El Matadero, S. 319: Y en efecto, el animal, acosado por los gritos y sobre todo por las picanas agudas que le espoleaban la cola, sintiendo flojo el lazo, arremetió bufando a la puerta, lanzando a entrambos lados una rojiza y fosfórica mirada. Dióle el tirón el enlazador sentando su caballo, desprendió el lazo de la asta, crujió por el aire un áspero zumbido y al mismo tiempo se vio rodar desde lo alto de una horqueta del corral, como si un golpe de hacha lo hubiese dividido a cercén, una cabeza de niño cuyo tronco permaneció inmóvil sobre su caballo de palo, lanzando por cada arteria un largo chorro de sangre.

El Matadero, S. 324: Sus fuerzas se habían agotado; inmediatamente quedó atado en cruz, y empezaron la obra de desnudarlo. Entonces un torrente de sangre brotó borbolloneando de su boca y las narices del joven, y extendiéndose, empezó a caer a chorros por entrambos lados de la mesa. Los sayones quedaron inmóviles y los espectadores estupefactos.

La Cautiva, Advertencia, S. 452: El principal designio del autor de La Cautiva ha sido pintar algunos rasgos de la fisonomía poética del desierto; y para no reducir su obra a una mera descripción, ha colocado, en las vastas soledades 
de la Pampa, dos seres ideales, o dos almas unidas por el doble vínculo del amor y el infortunio. El suceso que poetiza, si no cierto, al menos entra en lo posible; y como no es del poeta contar menuda y circunstancialmente a guisa de cronista o novelador, ha escogido sólo, para formar su cuadro, aquellos lances que pudieran suministrar más colores locales al pincel de la poesía; o más bien ha esparcido en torno de las dos figuras que lo componen, a algunos de los más peculiares ornatos de la naturaleza que los rodea.

\section{Fernández de Lizardi, José Joaquín: El Periquillo Sarniento. Prólogo de Jefferson Rea Spell. México: Editorial Porrúa "1970, S. 1: SENORES MÍOS: Una} de las cosas que me presentaba dificultad para dar a luz la VIDA DE PERIQUILLO SARNIENTO era elegir persona a quien dedicársela, porque yo he visto infinidad de obras, de poco y mucho mérito, adornadas con sus dedicatorias al principio.

S. 2: -Sí, amigo -le dije-, y ésta es una de las trabas más formidables que han tenido y tendrán los talentos americanos para no lucir, como debieran, en el teatro literario. Los grandes costos que tiene en el reino que lastarse en la impresión de las obras abultadas retraen a muchos de emprenderlas, considerando lo expuestos que están no sólo a no lograr el premio de sus fatigas, sino tal vez a perder hasta su dinero, quedándose inéditas en los estantes muchas preciosidades que darían provecho al público y honor a sus autores. Esta desgracia hace que no haya exportación de ninguna obra impresa aquí [...].

S. 3: - ¡Ay, hermano de mi alma! Tú me has dado un desengaño, pero al mismo tiempo una gran pesadumbre. Sí, tú me has abierto los ojos estrellándome en ellos una porción de verdades que por desgracia son irrefragables; y lo peor es que todo ello para en que yo pierdo mi trabajo; pues aunque soy limitado y, por lo mismo, de mis tareas no se puede esperar ninguna cosa sublime, sino bastante humilde y trivial, créeme, esta obrita me ha costado algún trabajo, y tanto más cuanto que soy un chambón y la he trabajado sin herramienta.

S. 3 f.: Muy bien sé que descendéis de un ingrato, y que tenéis relaciones de parentesco con los Caínes fratricidas, con los idólatras Nabucos, con las prostitutas Dalilas, con los sacrílegos Baltasares, con los malditos Canes, con los traidores Judas, con los pérfidos Sinones, con los Cacos ladrones, con los herejes Arrios, y con una multitud de pícaros y pícaras que han vivido y aún viven en el mismo mundo que nosotros. Sé que acaso seréis, algunos, plebeyos, indios, mulatos, negros, viciosos, tontos y majaderos. Pero no me toca acordaros nada de esto, cuando trato de captar vuestra benevolencia y afición a la obra que os dedico [...].

S. 12: Nací en México, capital de la América Septentrional, en la Nueva España. Ningunos elogios serían bastantes en mi boca para dedicarlos a mi cara patria; pero, por serlo, ningunos más sospechosos. Los que la habitan y los extranjeros que la han visto pueden hacer su panegírico más creíble, pues no 
tienen el estorbo de la parcialidad, cuyo lente de aumento puede a veces disfrazar los defectos, o poner en grande las ventajas de la patria aun a los mismos naturales; y así, dejando la descripción de México para los curiosos imparciales, digo: que nací en esta rica y populosa ciudad por los años de 1771 a 73, de unos padres no opulentos, pero no constituidos en la miseria; al mismo tiempo que eran de una limpia sangre, la hacían lucir y conocer por su virtud. ¡Oh, si siempre los hijos siguieran constantemente los buenos ejemplos de sus padres!

S. 99: Todavía hay pueblos donde los indios ponen a sus muertos un itacate, que es un envoltorio con cosas de comer y algunos realillos. En otros, a más de esto, les esconden un papel lleno de disparates para el Eterno Padre, y sus ofrendas son con igual superstición. En otro lugar diremos quiénes sostienen estos abusos.

S. 113: El buen ejemplo mueve más que los consejos, las insinuaciones, los sermones y los libros. Todo esto es bueno, pero, por fin, son palabras, que casi siempre se las lleva el viento. La doctrina que entra por los ojos se imprime mejor que la que entra por los oídos.

S. 401: Aprended, hombres, de mí, / lo que va de ayer a hoy; / que ayer conde y virrey fui / y hoy ni petatero soy. / / Ninguno viva engañado / creyendo que la fortuna / si es próspera, ha de ser una / sin volver su rostro airado. / Vivan todos con cuidado / cada uno mire por sí, / que es la suerte baladí, / y se muda a cada instante: / yo soy un ejemplo andante: / Aprended, hombres, de mí. / / Muy bien sé que son quimeras / las fortunas fabulosas, / pero hay épocas dichosas, / y llámense como quiera. / Si yo aprovechar supiera / una de éstas, cierto estoy / que no fuera como voy; / pero desprecié la dicha, / y ahora me miro en desdicha: / ¡lo que va de ayer a hoy! / / Ayer era un caballero / con un porte muy lucido; / y hoy me miro reducido / a unos calzones de cuero. / Ayer tuve harto dinero; / y hoy sin un maravedí, / me lloro, ¡triste de mi! / sintiendo mi presunción, / que aunque de imaginación / ayer conde y virrey fui. / / En este mundo voltario / fui ayer médico y soldado, / barbero, subdelegado, / sacristán y boticario. / Fui fraile, fui secretario, / y aunque ahora tan pobre estoy. / Fui comerciante en convoy, / estudiante y bachiller. / Pero jay de mi, esto fue ayer, / y hoy ni petatero soy!

S. 436 f.: Los libros morales es cierto que enseñan, pero sólo por los oídos; y por eso se olvidan sus lecciones fácilmente. Estos instruyen por los oídos y por los ojos. [...] Cuando leemos estos hechos nos parece que los estamos mirando, los retenemos en la memoria [...].

Flaubert, Gustave: à Louis Bouilhet. Dams, 4 septembre 1850. In: Ders.: Euvres complètes de Gustave Flaubert; Bd. 13-16: Correspondance 18501859. Paris: Société des études littéraires françaises. Éditeur scientifique 1974-1976, S. 74-79, hier 76 f.: Oui, la bêtise consiste à vouloir conclure. Nous sommes un fil et nous voulons savoir la trame. Cela revient à ces éternelles dis- 
cussions sur la décadence de l'art. Maintenant on passe son temps à se dire : nous sommes complètement finis, nous voilà arrivés au dernier terme, etc., etc. Quel est l'esprit un peu fort qui ait conclu, à commencer par Homère ? Contentons-nous du tableau ; c'est aussi bon. Et puis, ô pauvre vieux, est-ce qu'il n'y a pas le soleil (même le soleil de Rouen), l'odeur des foins coupés, les épaules des femmes de trente ans, le vieux bouquin au coin du feu et les porcelaines de la Chine? Quand tout sera mort, avec des brins de moelle de sureau et des débris de pot de chambre l'imagination rebâtira des mondes. Je suis bien curieux de le voir, ce brave conte chinois. Ce voyage-là me consolera des tristesses du retour. Je peux te dire une chose fortifiante et qui a le mérite d'être sincère, c'est que, comme nature, tu peux marcher hardiment. Tout ce que je vois ici, je le retrouve. (Il n'y a que les villes, les hommes, usages, costumes, ustensiles, choses de l'humanité enfin, dont je n'avais pas le détail net.) Je ne m’étais pas trompé. Pauvres diables que ceux qui ont des désillusions. Il y a des paysages où j'ai déjà passé, c'est certain. Retiens donc ceci pour ta gouverne, c'est le résultat d'une expérience faite exactement qui ne se dément point depuis dix mois c'est que nous sommes trop avancés en fait d'art pour nous tromper sur la nature. Ainsi, marche.

Foucault, Michel: Les mots et les choses. Paris: Gallimard 1966, S. 382 ff.: L'Histoire forme donc pour les sciences humaines un milieu d'accueil à la fois privilégié et dangereux. A chaque science de l'homme elle donne un arrière-fond qui l'établit, lui fixe un sol et comme une patrie : elle détermine la plage culturelle - l'épisode chronologique, l'insertion géographique - où on put reconnaître à ce savoir sa validité ; mais elle les cerne d'une frontière qui les limite, et ruine d'entrée de jeu leur prétention à valoir dans l'élément de l'universalité. [...] Même lorsqu'elles évitent toute référence à l'histoire, les sciences humaines (et à ce titre on peut placer l'histoire parmi elles) ne font jamais que mettre en rapport un épisode culturel avec un autre [...]. Toute connaissance s'enracine dans une vie, une société, un langage, qui ont une histoire ; et dans cette histoire même elle trouve l'élément qui lui permet de communiquer avec d'autres formes de vie, d'autres types de société, d'autres significations [...].

S. 398: Une chose en tout cas est certaine : c'est que l'homme n'est pas le plus vieux problème ni le plus constant qui se soit posé au savoir humain. En prenant une chronologie relativement courte et un découpage géographique restreint - la culture européenne depuis le XVIe siècle - on peut être sûr que l'homme y est une invention récente. Ce n'est pas autour de lui et de ses secrets que, longtemps, obscurément, le savoir a rôdé. En fait, parmi toutes les mutations qui ont affecté le savoir des choses et de leur ordre, le savoir des identités, des différences, des caractères, des équivalences, des mots, - bref au milieu de tous les épisodes de cette profonde histoire du Même - un seul, celui qui a commencé il y a un siècle 
et demi et qui peut-être est en train de se clore, a laissé apparaître la figure de l'homme. Et ce n'était point la libération d'une vieille inquiétude, passage à la conscience lumineuse d'un souci millénaire, accès à l'objectivité de ce qui longtemps était resté pris dans des croyances ou dans des philosophies : c'était l'effet d'un changement dans les dispositions fondamentales du savoir. L'homme est une invention dont l'archéologie de notre pensée montre aisément la date récente. Et peut-être la fin prochaine. Si ces dispositions venaient à disparaître comme elles sont apparues, si par quelque événement dont nous pouvons tout au plus pressentir la possibilité, mais dont nous ne connaissons pour l'instant encore ni la forme ni la promesse, elles basculaient, comme le fit au tournant du XVIIIe siècle le sol de la pensée classique, - alors on peut bien parier que l'homme s'effacerait, comme à la limite de la mer un visage de sable.

France, Anatole: L'anneau d'améthyste. In: ders.: Histoire contemporaine, Bd. III. Paris: Calmann-Lévy 1924, S. 235: Portant cette vision soudaine avait attristé les âmes, d'une flotte bénie par le Pape, battant le pavillon du roi catholique, portant à l'avant de ses navires les noms de la Vierge et des saints, désemparée, fracassée, coulée par les canons de ces marchands de cochons et ces fabricants de machines à coudre, hérétiques, sans rois, sans princes, sans passée, sans patrie, sans armée.

Galván, Manuel de Jesús: Enriquillo. Leyenda histórica dominicana (15031538). Santo Domingo: Ediciones de Taller 1985, S. 7: El nombre de Jaragua brilla en las primeras páginas de la historia de América con el mismo prestigio que en las edades antiguas y en las narraciones mitológicas tuvieron la inocente Arcadia, la dorada Hesperia, el bellísimo valle de Tempé, y algunas otras comarcas privilegiadas del globo, dotadas por la Naturaleza con todos los encantos que pueden seducir la imaginación, y poblarla de quimeras deslumbradoras. Como ellas, el reino indio de Jaragua aparece ante los modernos argonautas que iban a conquistarlo, bajo el aspecto de una región maravillosa, rica y feliz. Regido por una soberana hermosa y amable; habitado por una raza benigna, de entendimiento despejado, de gentiles formas físicas; su civilización rudimentaria, por la inocencia de las costumbres, por el buen gusto de sus sencillos atavíos, por la graciosa disposición de sus fiestas y ceremonias, y más que todo, por la expansión generosa de su hospitalidad, bien podría compararse ventajosamente con esa otra civilización que los conquistadores, cubiertos de hierro, llevaban en las puntas de sus lanzas, en los cascos de sus caballos, y en los colmillos de sus perros de presa.

S. 123 f.: Pertenecía el Contador real Don Cristóbal de Cuéllar, por sus principios y sus ideas, al siglo en que había nacido; ese fecundo siglo décimo quinto, que cierra la tenebrosa Edad Media con la caída del Imperio de Oriente, la con- 
quista de Granada y el descubrimiento del Nuevo Mundo. Mitad sombra y mitad luz, aquella centuria, al espirar, preludiaba dignamente al gran siglo del Renacimiento de las letras y las artes, á que tanto contribuyó la emigración á Italia de los más ilustres sabios y literatos de la ya mahometana Constantinopla. [...] Imponíase entonces á la conciencia de los pueblos la idea de la real potestad, como hoy se impone la idea democrática bajo la forma racional de la República, consecuencia del mayor adelanto de las ciencias morales y políticas.

S. 204 f.: Al cabo de tres días llegaron á la ciudad de Concepción de la Vega. Era la época del año en que de todos los puntos de la isla donde laboraban minas, concurrían los colonos á aquel centro de población á fundir sus minerales y someterlos á la marca de ley; por cuya causa la Vega ofrecía tanta ó mayor animación que la capital: celebrábase al mismo tiempo feria, á la que acudían presurosos desde los últimos rincones del territorio todos los que tenían algún objeto, animales y fruslerías de que hacer almoneda. Por las calles principales bullía la gente con festiva algazara [...].

S. 212 f. [Las Casas]: Creo cierto que otra vista tan graciosa y deleitable, y que tanto refrigere y bañe de gozo y alegría las entrañas, en todo el orbe no parece que pueda ser oída ni imaginada, por que toda esta vega tan grande, tan luenga y larga, es más llana que la palma de la mano; está toda pintada de yerba, la más hermosa que puede decirse y odorífera, muy diferente de la España; píntanla de legua á legua, ó de dos á dos leguas, arroyos graciosísimos que la atraviesan, cada uno de los cuales lleva por las rengleras de sus ámbas á dos riberas su lista ó ceja ó raya de árboles, siempre verdes, tan bien puestos y ordenados, como si fueran puestos á mano, y que no ocupan poco más de 15 ó 20 pasos en cada parte. [...] Tengo por averiguado que ningún hombre y sábio que hubiese bien visto y considerado la hermosura y alegría y amenidad y postura desta vega, no tendría por vano el viaje desde Castilla hasta acá, del que siendo filósofo curioso ó cristiano devoto, solamente para verla [...].

S. 456f.: Algún tiempo se mostró preocupada y triste; su soledad le parecía espantosa, mientras que Enrique, su amado compañero, estaba enteramente consagrado á la organización y defensa de su montañoso estado. Mas, cuando por primera vez el valiente cacique se presentó á sus ojos victorioso; cuando arrojó á los piés de ella la espada inútil del arrogante Valenzuela; cuando cubierto aun con el polvo del combate se le mostró grande, verdaderamente libre, con la aureola augusta del valor heróico y de la dignidad recobrada, entonces el corazón de Mencía palpitó á impulsos de imponderable satisfacción y de legítimo orgullo, y arrojándose en los brazos del conmovido guerrero, besó con santo entusiasmo $\mathrm{su}$ rostro varonil; corrieron sus cristalinas lágrimas por el robusto y polvoroso cuello del caudillo, y sus labios, trémulos de grata emoción, murmuraron apenas esta frase expresiva: -Grande, libre, vengado... ; -jasí te quiero! 
S. 474: Este nombre vive y vivirá eternamente: un gran lago lo perpetúa con su denominación geográfica; las erguidas montañas del Bahoruco parecen como que lo levantan hasta la región de las nubes, y á cualquier distancia que se alcance á divisarlas en su vasto desarrollo, la sinuosa cordillera, destacando sus altas cimas sobre el azul de los cielos, contorneando los lejanos horizontes, evoca con muda elocuencia el recuerdo glorioso de Enriquillo.

\section{Gómez de Avellaneda, Gertrudis: Sab. Edición, prólogo y notas de Carmen} Bravo Villasante. Madrid: Ediciones Anaya 1970, S. 42: No parecía un criollo blanco, tampoco era negro ni podía creérsele descendiente de los primeros habitantes de las Antillas. Su rostro presentaba un compuesto singular en que se descubría el cruzamiento de dos razas diversas, y en que se amalgamaban, por decirlo así, los rasgos de la casta africana con los de la europea, sin ser no obstante un mulato perfecto. Era su color de un blanco amarillento con cierto fondo oscuro; su ancha frente se veía cubierta con mechones desiguales de un pelo negro y lustroso como las alas del cuervo; su nariz era aguileña pero sus labios gruesos y amoratados denotaban su procedencia africana, tenía la barba un poco prominente y triangular, los ojos negros, grandes, rasgados, bajo cejas horizontales, brillando en ellos el fuego de la primera juventud, no obstante que surcaban su rostro ligeras arrugas. El conjunto de estos rasgos formaba una fisonomía, una característica, una de aquellas fisonomías que fijan las miradas a primera vista y que jamás se olvidan cuando se han visto una vez.

S. 69: ¡Pues qué! ¿no hay siete días de diferencia? ¡Siete días, Enrique! Otros tantos he estado sin verte en esta primera separación y me han parecido una eternidad. ¿No has experimentado tú cuán triste cosa es ver salir el sol, un día y otro... sin que pueda disipar las tinieblas del corazón, sin traernos un rayo de esperanza... porque sabemos que no veremos con su luz el semblante a dorado? Y luego, cuando llega la noche, cuando la naturaleza se adormece en medio de las sombras y las brisas, ¿no has sentido tu corazón inundarse de una ternura dulce, indefinible como el aroma de las flores?... ¿No has experimentado una necesidad de oír la voz querida en el silencio de la noche? ¿No te ha agobiado la ausencia, ese malestar continuo, ese vacío inmenso, esa agonía de un dolor que se reproduce bajo mil formas diversas, pero siempre punzante, inagotable, insufrible?

S. 114 f.: ¡Oh, Enrique! lloro no haber nacido entonces, y que tú, indio como yo, me hicieses una cabaña de palmas en donde gozásemos una vida de amor, de inocencia y de libertad. Enrique se sonrió del entusiasmo de su querida haciéndola una caricia; el mulato apartó de ella sus ojos preñados de lágrimas. - ¡Ah!, ¡sí! -pensó él-; no serías menos hermosa si tuvieras la tez negra o cobriza. ¿Por qué no lo ha querido el cielo, Carlota? Tú, que comprendes la vida y la felicidad 
de los salvajes, ¿por qué no naciste conmigo en los abrasados desiertos del Africa o en un confín desconocido de la América?

Gómez de Avellaneda, Gertrudis: Guatimozín In Dies.: Obras de doña Gertrudis de Avellaneda. Bd. 5. Madrid: Ediciones Atlas 1981, S. 207: Tres años, poco más o menos, habían transcurrido desde el día memorable en que - vencido y prisionero el joven y heroico Emperador Guatimozín - se rindió a las armas españolas, después de noventa y tres días de formidable sitio, la hermosa capital del imperio mexicano. Tres años se contaban ya de aquel gran suceso, cuya inmensa resonancia aún conmovía profundamente la Europa, y no había sido posible todavía al caudillo vencedor - no obstante su genio y su fortuna - sujetar por completo todas las provincias de la vasta Nueva España, conquistada por su acero para la antigua corona de Castilla, pero aquel tiempo había bastado sobradamente para amargarle con íntimos sacrificios de su corazón y vergonzosas defecciones de su propia gente, las dulzuras embriagadoras de la gloria.

\section{Gómez de Avellaneda, Gertrudis: Autobiografía y epistolarios de amor.} Newark US: Juan de la Cuesta 1999, S. 52 f.: Sin embargo, nunca fui alegre y atolondrada como lo son regularmente los niños. Mostré desde mis primeros años afición al estudio y una tendencia a la melancolía. No hallaba simpatías en las niñas de mi edad; tres solamente, vecinas mías, hijas de un emigrado de Santo Domingo merecieron mi amistad. Eran tres lindas criaturas de un talento natural despejadísimo. [...] Las Carmonas (que este era su apellido) se conformaban facilmente con mis gustos y los participaban. Nuestros juegos eran representar comedias, hacer cuentos, rivalizando a quien los hacía más bonitos, adivinar charadas y dibujar en competencia flores y pajaritos. Nunca nos mezclábamos en los bulliciosos juegos de las otras chicas con quienes nos reuníamos. Más tarde, la lectura de novelas, poesías y comedias llegó a ser nuestra pasión dominante. Mamá nos reñía algunas veces de que siendo ya grandecitas, descuidásemos tanto nuestros adornos, y huyésemos de la sociedad como salvajes. Porque nuestro mayor placer era estar encerradas en el cuarto de los libros, leyendo nuestras novelas favoritas y llorando las desgracias de aquellos héroes imaginarios, a quienes tanto queríamos. De este modo cumplí trece años. ¡Días felices, que pasaron para no tornar más!...

S. 62 f.: El día 9 de abril de 1836 nos embarcamos para Burdeos en una fragata francesa, y sentidas y lloradas, abandonamos, ingratas, aquel país querido, que acaso no volveremos a ver jamás. Perdone usted; mis lágrimas manchan este papel; no puedo recordar sin emoción aquella noche memorable en que vi por última vez la tierra de Cuba. La navegación fue para mí un manantial de nuevas emociones. -«Cuando navegamos sobre los mares azulados, ha dicho Lord 
Byron, nuestros pensamientos son tan libres como el Océano.»- Su alma sublime y poética debió sentirlo así: la mía lo experimentó también. Hermosas son las noches de los trópicos, y yo las había gozado; pero son más hermosas las noches del Océano. Hay un embeleso indefinible en el soplo de la brisa que llena las velas, ligeramente estremecidas, en el pálido resplandor de la luna que reflejan las aguas, en aquella inmensidad que vemos sobre nuestra cabeza y bajo nuestros pies. Parece que Dios se revela mejor al alma conmovida en medio de aquellos dos infinitos - ¡el cielo y el mar!- y que una voz misteriosa se hace oír en el ruido de los vientos y de las olas. Si yo hubiese sido atea, dejaría de serlo entonces.

S. 73: La educación que se da en Cuba a las señoritas difiere tanto de la que se les da en Galicia, que una mujer, aún de la clase media, creería degradarse en mi país ejercitándose en cosas que en Galicia miran las más encopetadas como una obligación de su sexo. Las parientas de mi padrastro decían, por tanto, que yo no era buena para nada, porque no sabía planchar, ni cocinar, ni calcetear; porque no lavaba los cristales, ni hacía las camas, ni barría mi cuarto. Según ellas, yo necesitaba veinte criadas y me daba el tono de una princesa. Ridiculizaban también mi afición al estudio y me llamaban la Doctora. [...] Luego que rompí mis compromisos y me vi libre, aunque no más dichosa; persuadida de que no debía casarme jamás y de que el amor da más penas que placeres, me propuse adaptar un sistema, que ya hacía algún tiempo tenía en mi mente. Quise que la vanidad reemplazase al sentimiento, y me pareció que valía más agradar generalmente que ser amada de uno sólo: tanto más cuanto que este uno nunca sería un objeto que llenase mis votos. Yo había perdido la esperanza de encontrar un hombre según mi corazón.

\section{Hostos, Eugenio María de: La Peregrinación de Bayoán. Novela. In (ders.):} Obras Completas. Bd. VIII. La Habana: Editorial Comercial 1939, S. 9: Le puse un libro cualquiera en las manos, le rogué que esperase, y dejándolo solo en una de mis dos habitaciones, pasé a la otra. Tomé pluma, tinta, papel, y escribí. A la media hora salí radiante de alegría, y gritando: Aquí está el libro, leí a Rada los seis primeros diarios de La Peregrinación de Bayoán. Rada quiso leer más, y se obstinó y porfió por leer más. Cuando le dije que no había más, se quedó estupefacto. Cuando le dije que lo leído acababa de ser escrito, el asombro que mostró fué mi recompensa y fué mi estímulo. -Pero y ¿y el libro?- insistió. [...] -Mañana.Es imposible. -Usted lo verá. Mecánicamente, es imposible que yo escriba ese libro en veinticuatro horas; pero intelectualmente es posible, puesto que acabo de concebirlo y de escribirlo en mi cerebro.

S. 17f.: Así ligados en una encadenación lógica de ideas los dos aspectos que había percibido, me parecía que todo el libro, que todas sus intenciones, que todas sus reticencias, caerían como acusaciones fulminantes contra España. Acusada 
por una pluma justiciera, la conciencia del mundo la condenaría. Acusada por un patriotismo convincente, todos los patriotas de las Antillas la maldecirían. De la maldición a la explosión, un solo paso! Yo había dado el primero, yo podría dar el segundo.

S. 78: Yo he hecho infelices a cuantos me han rodeado, yo me he hecho infeliz. Mi implacable razón no me abandona, y por no avergonzarse un día de un tropiezo, me niega la ventura que le pido. A tus instancias, oye lo que contesta, corazón. «Tú estás condenado a no amar: si amas, haces infeliz: si no también: pero si amando resistes a tu amor y buscas tu deber, que está llamándote, yo te prometo un día la luz más refulgente: tu deber te llama lejos de aquí: obedece: si vas, y te aman, sacrificas hoy...: el tiempo cura: si amas y olvidas tu deber, acuérdate de tu conciencia!» Y yo, entre tanto, amo, no veo a la que amo, no digo cuanto amo, me privo de la luz: quiero quedarme, y me empujan; quiero partir, y me llaman! Y el amor es el cielo...! - me decía yo ayer. ¡Oh razón, oh razón, maldita seas!

S. 138: Veo un mundo fantástico, semejante a la tierra: en las llanuras, en las vegas, en las costas, en todo lo que se parece, es igual y está a un nivel, atmósfera tranquila: en los montes, neblinas; en los Andes, nubes eternas, sombrías. Los hombres son los llanos, las playas, lo a un nivel; el hombre que se eleva, el Chimborazo, ardiendo interiormente en fuego eterno, cubierto exteriormente de nubes perdurables. -¡Medita en la alegoría...!

S. 175: Febrero 27. ¡Qué magnífico ocaso! El sol se ha puesto: luchando con las sombras, su último rayo colora el horizonte: y ese rayo, esparciéndose, hace milagros. Allí está el mar de nácar que tantas veces he admirado: abarcándolo, una tierra de color oscuro; poblándolo, millares de islas, de escollos, de peñascos; cruzándolo, vapores ligerísimos que tienen a mis ojos la forma de los buques. De la tierra que lo abarca, ha brotado una montaña: ¡qué montaña! ¿hay alguna en la tierra que imite la osadía con que ésa se levanta en el espacio? ¿hay alguna que imite sus corrientes de brillantes, sus torrentes sombríos, sus árboles inmensos, sus bosques colosales, la aureola que corona su cúspide? Cerca de la montaña, una caverna: veo su profundidad a favor de esa luz color de púrpura: y a favor de esa luz, veo esos fantasmas, esos mónstruos extraños, esas sombras pavorosas, queriendo penetrar en ella, y empujándose, codeándose, impidiéndose el paso, golpeándose, destruyéndose, y volviendo a la nada o transformándose. Todo va desvaneciéndose: la caverna y sus mónstruos se disipan; la montaña se hunde; el mar de nácar se sumerge. Ocupan su lugar formas ligeras, nubecillas blancas, vapores sin forma que flotan, oscilan, se mueven, y se ocultan. Allí vienen las sombras de la noche: ennegrecen primero el horizonte opuesto, invaden el zenit, sombrean el occidente, desvanecen los últimos colores que ha dejado la luz, oscurecen el cielo. De esas sombras, va naciendo un azul claro en oriente, oscuro en 
occidente: aparece una estrella, luego otra, ahora mil. Reina la noche: ni colores, ni sombras, ni vapores en el ocaso. Oscureció: ya, nada... ¡Sí! En mi cerebro hay un pensamiento triste, una comparación amarga. La imaginación es un sol que se pone eternamente: engendra un mundo, lo colora con el resplandor de su invisible fuego, y cuando va a perfeccionarlo, su mundo se oculta tras un vuelo, el vapor de una noche irremediable lo sombrea, y la oscuridad lo desvanece. En el cielo recuerdan las estrellas la luz del sol ya puesto: en la imaginación no queda nada; el aire es nada.

\section{Hugo, Victor: Bug-Jargal. Berlin: W. Natorff et Compagnie 1836, Préface vom} 24. März 1832, s.p.: En 1818, l'auteur de ce livre avait seize ans ; il paria qu'il écrirait un volume en quinze jours. Il fit Bug-Jargal. Seize ans, c'est l'âge où l'on parie pour tout et où l'on improvise sur tout. Ce livre a donc été écrit deux ans avant Han d'Islande. Et quoique, sept ans plus tard, en 1825, l'auteur l'ait remanié et récrit en grande partie, il n'en est pas moins, et par le fond et par beaucoup de détails, le premier ouvrage de l'auteur. [...] et, quant à lui, comme ces voyageurs qui se retournent au milieu de leur chemin et cherchent à découvrir encore dans les plis brumeux de l'horizon le lieu d'où ils sont partis, il a voulu donner ici un souvenir à cette époque de sérénité, d'audace et de confiance, où il abordait de front un si immense sujet, la révolte des noirs de Saint-Domingue en 1791, lutte de géants, trois mondes intéressés dans la question, l'Europe et l'Afrique pour combattants, l'Amérique pour champ de bataille.

S. 52 u. 59: En causant avec lui, je remarquai qu'il parlait avec facilité le français et l'espagnol, et que son esprit ne paraissait pas dénué de culture ; il savait des romances espagnoles qu'il chantait avec expression. Cet homme était si inexplicable, sous tant d'autres rapports, que jusqu'alors la pureté de son langage ne m'avait pas frappé. [...] En passant près des cases de nos noirs, je fus surpris de l'agitation extraordinaire qui y régnait. La plupart étaient encore éveillés et parlaient avec la plus grande vivacité. Un nom bizarre, Bug-Jargal, prononcé avec respect, revenait souvent au milieu de leur jargon inintelligible. Je saisis pourtant quelques paroles, dont le sens me parut être que les noirs de la plaine du nord étaient en pleine révolte, et livraient aux flammes les habitations et les plantations situées de l'autre côté du Cap.

S. 64: Voici les rapports qui me sont parvenus. La révolte a commencé cette nuit à dix heures du soir parmi les nègres de l'habitation Turpin. Les esclaves, commandés par un nègre anglais nommé Boukmann, ont entraîné les ateliers des habitations Clément, Trémès, Flaville, et Noé. Ils ont incendié toutes les plantations et massacrés des colons avec des cruautés inouïes. Je vous en ferai comprendre toute l'horreur par un seul détail. Leur étandard est le corps d'un enfant porté au bout d'une pique. Un frémissement interrompit M. de Blanchelande. - Voilà 
ce qui se passe au-dehors, poursuivit-il. Au-dedans, tout est bouleversé. Plusieurs habitants du Cap ont tué leurs esclaves ; la peur les a rendus cruels. Les plus doux ou les plus braves se sont bornés à les enfermer sous bonne clef. Les petits blancs accusent de ces désastres les sang-mêlés libres. Plusieurs mulâtres ont failli être victimes de la fureur populaire. Je leur ai fait donner pour asyle une église gardée par un bataillon. Maintenant, pour prouver qu'ils ne sont point d'intelligence avec les noirs révoltés, les sang-mêlés me font demander un poste à défendre et des armes.

S. 69 f.: Ce sont les beaux parleurs et les avocats qui gâtent tout, ici comme dans ta métropole. Si j'avais l'honneur d'être monsieur le lieutenant-général pour le roi, je jetterais toute cette canaille à la porte. Je dirais : Le roi règne, et moi je gouverne. J'enverrais la responsabilité par-devant les soi-disant représentants à tous les diables ; et avec douze croix de Saint-Louis, promises au nom de sa majesté, je balaierais tous les rebelles dans l'île de la Tortue, qui a été habitée autrefois par des brigands comme eux, les boucaniers. Souvenez-vous de ce que je vous dis, jeune homme. Les philosophes ont enfanté les philanthropes, qui ont procréé les négrophiles, qui produisent les mangeurs de blancs, ainsi nommés en attendant qu'on leur trouve un nom grec ou latin. Ces prétendues idées libérales dont on s'enivre en France sont un poison sous les tropiques. Il fallait traiter les nègres avec douceur, non les appeler à un affranchissement subit. Toutes les horreurs que vous voyez aujourd'hui à Saint-Domingue sont nées au club Massiac, et l'insurrection des esclaves n'est qu'un contrecoup de la chute de la Bastille.

S. 169 f.: Au-dessus de toutes ces têtes flottaient des drapeaux de toutes couleurs, de toutes devises, blancs, rouges, tricolores, fleurdelysés, surmontés du bonnet de liberté, portant pour inscription :-Mort aux prêtres et aux aristocrates !-Vive la religion!-Liberté !-Egalité !-Vive le roi !-A bas la métropole !-Viva España! -plus de tyrans ! etc. Confusion frappante qui indiquait que toutes les forces des rebelles n'étaient qu'un amas de moyens sans but, et qu'en cette armée il n'y avait pas moins de désordre dans les idées que dans les hommes. [...] Ce flot de barbares et de sauvages passa enfin.

Humboldt, Alexander von: Mes confessions, à lire et à me renvoyer un jour. In: Le Globe (Genève) 7 (janvier - février 1868), S. 180-190, hier S. 182: Au printems, M. Georges Forster, avec qui j'avais lié connaissance à Mayence, me proposa de le suivre en Angleterre dans ce voyage rapide qu'il a décrit dans un petit ouvrage (Ansichten, etc.) justement célèbre par l'élégance du style. [...] Ce voyage cultivant mon esprit me décida aussi plus que jamais pour le voyage hors d'Europe. Je vis alors la première fois la mer à Ostende, et je me souviens que cette vue fit la plus grande impression sur moi. Je vis moins la mer que les pays auquels cet élément devait un jour me porter. 
S. 188: Inquiet, agité et ne jouissant jamais de ce que j’ai achevé, je ne suis heureux qu'en entreprenant du nouveau et en faisant trois choses à la fois. C'est dans cet esprit d'inquiétude morale, suite d'une vie nomade, que l'on doit chercher les causes principales de la grande imperfection de mes ouvrages. J'aurai été plus utile par les choses et les faits que j'ai rapportés, par les idées que j'ai fait naître dans d'autres, que par les ouvrages que j'ai publié moi-même. Cependant je n'ai pas manqué ni de bonne et de grande volonté, ni d'assiduité au travail. Dans les climats les plus ardents du globe, j'ai écrit ou dessiné souvent 15 à 16 heures de suite. Ma santé n'en a pas soufferte, et je me prépare au voyage d’Asie après avoir publié les résultats du voyage d’Amérique.

Humboldt, Alexander von: Relation historique du Voyage aux Régions équinoxiales du Nouveau Continent fait en 1799, 1800, 1801,1802,1803, et 1804 par Al. de Humboldt et A. Bonpland rédigé par Alexandre de Humboldt. Neudruck des 1814-1825 in Paris erschienenen vollständigen Originals, besorgt, eingeleitet und um ein Register vermehrt von Hanno Beck. 3 Bde. Stuttgart: Brockhaus, 1970, hier Bd. III, S. 58-59: Sans doute qu'après les grandes révolutions que subit l'état des sociétés humaines, la fortune publique, qui est le patrimoine commun de la civilisation, se trouve différemment répartie entre les peuples des deux mondes; mais peu à peu l'équilibre se rétablit, et c'est un préjugé funeste, j'oserois presque dire impie, que de considérer comme une calamité pour la vieille Europe la prospérité croissante de toute autre portion de notre planète. L'indépendance des colonies ne contribuera pas à les isoler, elle les rapprochera plutôt des peuples anciennement civilisés. Le commerce tend à unir ce qu'une politique jalouse a séparé depuis long-temps. Il y a plus encore : il est de la nature de la civilisation de pouvoir se porter en avant sans s'éteindre pour cela dans le lieu qui l'a vu naître. Sa marche progressive de l'est à l'ouest, de l'Asie en Europe, ne prouve rien contre cet axiome. Une vive lumière conserve son éclat même lorsqu'elle éclaire un plus grand espace. La culture intellectuelle, source féconde de la richesse nationale, se communique de proche en proche ; elle s'étend sans se déplacer.

Bd. III, S. 249 f.: Cette nouvelle nous causa d'autant plus d'horreur que peu de jours avant notre embarquement nous était venue la gazette avec l'affreux discours de Bruix dans lequel comme orateur du Gouvernement il propose au Corps législatif de réintroduire l'Esclavage et la traite des Nègres de la même manière qu'elle subsistait avant 1789. Nous étions heureusement dans une société dans laquelle beaucoup de personnes partageaient l'horreur morale avec laquelle on doit recevoir une nouvelle aussi affligeante. Voilà donc le fruit de tant de sang répandu aux Indes [...].

Bd. III, S. 348: L'aspect de la Havane, à l'entrée du port, est un des plus rians et des plus pittoresques dont on puisse jouir sur le littoral de l'Amérique équi- 
noxiale, au nord de l'équateur. Ce site, célébré par les voyageurs de toutes les nations, n'a pas le luxe de végétation qui orne les bords de la rivière de Guayaquil, ni la sauvage majesté des côtes rocheuses de Rio Janeiro, deux ports de l'hémisphère austral: mais la grâce qui, dans nos climats, embellit les scènes de la nature cultivée, se mêlent ici à la majesté des formes végétales, à la vigueur organique qui caractérise la zone torride. Dans un mélange d'impressions si douces, l'Européen oublit le danger qui le menace au sein des cités populeuses des Antilles; il cherche à saisir les élémens divers d'un vaste paysage à contempler ces châteaux forts qui couronnent les rochers à l'est du port, ce bassin intérieur, entouré de villages et de fermes, ces palmiers qui s'élèvent à une hauteur prodigieuse, cette ville à demi cachée par une forêt de mâts et la voilure des vaisseaux.

Bd. III, S. 389: Si la législation des Antilles et l'état des gens de couleur n'éprouvent pas bientôt des changemens salutaires, si l'on continue à discuter sans agir, la prépondérance politique passera entre les mains de ceux qui ont la force du travail, la volonté de s'affranchir et le courage d'endurer de longues privations. Cette catastrophe sanglante aura lieu comme une suite nécessaire des circonstances, et sans que les noirs libres d'Haïti s'en mêlent aucunement, sans qu'ils abandonnent le système d'isolement qu'ils ont suivi jusqu'ici. Qui oseroit prédire l'influence qu'exerceroit une Confédération africaine des Etats libres des Antilles, placée entre Colombia, l’Amérique du Nord et Guatimala, sur la politique du Nouveau-Monde?

\section{Humboldt, Alexander von: Briefe aus Amerika 1799-1804. Bearbeitet von} Ulrike Moheit. Berlin: Akademie Verlag 1993, S. 300: Plus que les événemens récens de S. Domingue ont offusqué la vérité et plus il paraît du devoir de tout homme moral de replacer le problème dans son vrai jour. [...] Qu'il serait beau si les Etats méridionaux préparaient la chose sans attendre la Crise dangereuse de l'an 1808. Cette abominable loi qui permet l'importation des Nègres dans la Caroline méridionale est un opprobre pour un Etat, dans lequel je sais qu'ils existent des têtes très bien organisées. En suivant la seule marche que dicte l'humanité, on exportera sans doute au commencement moins de Coton. Mais hélas ! que je déteste cette Politique qui mesure et évalue la félicité publique simplement d'après la valeur des Exportations ! [...] Avant d'être libre, il faut être juste, et sans justice il n'y a pas de prospérité durable.

Huysmans, Joris-Karl: A rebours. Paris: Georges Crès 1922, S. 60 f.: L’orgue se trouvait alors ouvert. Les tiroirs étiquetés «flûte, cor, voix céleste» étaient tirés, prêts à la manœuvre. Des Esseintes buvait une goutte, ici, là, se jouait des symphonies intérieures, arrivait à se procurer, dans le gosier, des sensations analogues à celles que la musique verse à l'oreille. Du reste, chaque liqueur correspon- 
dait, selon lui, comme goût, au son d'un instrument. Le curaçao sec, par exemple, à la clarinette dont le chant est aigrelet et velouté; le kummel au hautbois dont le timbre sonore nasille; la menthe et l'anisette, à la flûte, tout à la fois sucrée et poivrée, piaulante et douce [...]. Il pensait aussi que l'assimilation pouvait s'étendre, que des quatuors d'instruments à cordes pouvaient fonctionner sous la voûte palatine, avec le violon représentant la vieille eau-de-vie [...]. La similitude se prolongeait encore: des relations de tous tons existaient dans la musique des liqueurs; ainsi pour ne citer qu'une note, la bénédictine figure, pour ainsi dire, le ton mineur de ce ton majeur des alcools que les partitions commerciales désignent sous le signe de chartreuse verte. Ces principes une fois admis, il était parvenu, grâce à d'érudites expériences, à se jouer sur la langue de silencieuses mélodies, de muettes marches funèbres à grand spectacle, à entendre, dans sa bouche, des solis de menthe, des duos de vespétro et de rhum.

S. 68 ff.: Entre tous, un artiste existait dont le talent le ravissait en de longs transports, Gustave Moreau. Il avait acquis ses deux chefs-d'œuvre et, pendant des nuits, il rêvait devant l'un d'eux, le tableau de la Salomé, ainsi conçu: Un trône se dressait, pareil au maître-autel d'une cathédrale, sous d'innombrables voûtes jaillissants de colonnes trapues ainsi que des piliers romans, émaillées de briques polychromes, serties de mosaïques, incrustées de lapis-lazuli et de sardoines, dans un palais semblable à une basilique d'une architecture tout à la fois musulmane et byzantine. Au centre du tabernacle surmontant l'autel précédé de marches en forme de demi-vasques, le Tétrarque Hérode était assis, coiffé d'une tiare, les jambes rapprochées, les mains sur les genoux. La figure était jaune, parcheminée, annelée de rides, décimée par l'âge; sa longue barbe flottait comme un nuage blanc sur les étoiles enpierreries qui constellaient la robe d'orfroi plaquée sur sa poitrine. Autour de cette statue, immobile, figée dans une pose hiératique de dieu hindou, des parfums brûlaient, dégorgeant des nuées de vapeurs que trouaient, de même que les yeux phosphorés de bêtes, les feux des pierres enchâssées dans les parois du trône; puis la vapeur montait, se déroulait sous les arcades où la fumée bleue se mêlait à la poudre d'or des grands rayons de jour, tombés des dômes. Dans l'odeur perverse des parfums, dans l'atmosphère surchauffée de cette église, Salomé, le bras gauche étendu, en un geste de commandement, le bras droit replié, tenant à la hauteur du visage, un grand lotus, s'avance lentement sur les pointes, aux accords d'une guitare dont une femme accroupie pince les cordes. La face recueillie, solennelle, presque auguste, elle commence la lubrique danse qui doit réveiller les sens assoupis du vieil Hérode; ses seins ondulent et, au frottement de ses colliers qui tourbillonnent, leurs bouts se dressent; sur la moiteur de sa peau les diamants, attachés, scintillent; ses bracelets, ses ceintures, ses bagues, crachent des étincelles; sur sa robe triomphale, couturée de perles, ramagée d'argent, lamée d'or, la cuirasse des orfèvreries dont chaque maille est une pierre, entre en combustion, 
croise des serpenteaux de feu, grouille sur la chair mate, sur la peau rose thé, ainsi que des insectes splendides aux élytres éblouissants, marbrés de carmin, ponctués de jaune aurore, diaprés de bleu d'acier, tigrés de vert paon. Concentrée, les yeux fixes semblables à une somnambule, elle ne voit ni le Tétrarque qui frémit, ni sa mère, la féroce Hérodias, qui la surveille, ni l'hermaphrodite ou l'eunuque qui se tient, le sabre au poing, en bas du trône, une terrible figure, voilée jusqu'aux joues, et dont la mamelle de châtré pend, de même qu'une gourde, sous sa tunique bariolée d'orange. Ce type de la Salomé si hantant pour les artistes et pour les poètes, obsédait, depuis des années, des Esseintes.

S. 145 ff.: Il était, depuis des années, habile dans la science du flair; il pensait que l'odorat pouvait éprouver des jouissances égales à celles de l'ouïe et de la vue, chaque sens étant susceptible, par suite d'une disposition naturelle et d'une érudite culture, de percevoir des impressions nouvelles, de les décupler, de les coordonner, d'en composer ce tout qui constitue une œuvre; et il n'était pas, en somme, plus anormal qu'un art existât, en dégageant d'odorants fluides, que d'autres, en détachant des ondes sonores, ou en frappant de rayons diversement colorés la rétine d'un œil [...]. Dans cet art des parfums, un côté l'avait, entre tous, séduit, celui de la précision factice. Presque jamais, en effet, les parfums ne sont issus des fleurs dont ils portent le nom; l'artiste qui oserait emprunter à la seule nature ses éléments, ne produirait qu'une œuvre bâtarde, sans vérité, sans style, attendu que l'essence obtenue par la distillation des fleurs ne saurait offrir qu'une très lointaine et très vulgaire analogie avec l'arôme même de la fleur vivante, épandant ses effluves, en pleine terre. [...] Peu à peu, les arcanes de cet art, le plus négligé de tous, s'étaient ouverts devant Des Esseintes qui déchiffrait maintenant cette langue, variée, aussi insinuante que celle de la littérature, ce style d'une concision inouïe, sous son apparence flottante et vague. Pour cela, il lui avait d'abord fallu travailler la grammaire, comprendre la syntaxe des odeurs, se bien pénétrer des règles qui les régissent [...].

Kristeva, Julia: Soleil noir. Dépression et mélancolie. Paris: Gallimard 1987, S. 64: L'effondrement spectaculaire du sens chez le dépressif - et, à l'extrême, du sens de la vie - nous laisse donc présupposer qu'il a du mal à intégrer la chaîne signifiante universelle, le langage. Dans le cas idéal, l'être parlant fait un avec son discours : la parole n'est-elle pas notre «seconde nature»? Au contraire, le dire du dépressif est pour lui comme une peau étrangère : le mélancolique est un étranger dans sa langue maternelle. Il a perdu le sens - la valeur - de sa langue maternelle, faute de perdre sa mère. La langue morte qu'il parle et qui annonce son suicide cache une Chose enterrée vivante. Mais celle-ci, il ne la traduira pas pour ne pas la trahir : elle restera emmurée dans la «crypte» de l'affect indicible, captée analement, sans issue. 
Lévi-Strauss, Claude: Race et histoire. Paris: UNESCO 1952, S. 76 f.: Nous avons, au contraire, cherché à montrer que la véritable contribution des cultures ne consiste pas dans la liste de leurs inventions particulières, mais dans l'écart différentiel qu'elles offrent entre elles. [...] D’autre part, nous avons considéré la notion de civilisation mondiale comme une sorte de concept limite, ou comme une manière abrégée de désigner un processus complexe. Car si notre démonstration est valable, il n'y a pas, il ne peut y avoir, une civilisation mondiale au sens absolu que l'on donne souvent à ce terme, puisque la civilisation implique la coexistence de cultures offrant entre elles le maximum de diversité, et consiste même en cette coexistence. La civilisation mondiale ne saurait être autre chose que la coalition, à l'échelle mondiale, de cultures préservant chacune son originalité.

S. 85: La tolérance n'est pas une position contemplative, dispensant les indulgences à ce qui fut ou à ce qui est. C'est une attitude dynamique, qui consiste à prévoir, à comprendre et à promouvoir ce qui veut être. La diversité des cultures humaines est derrière nous, autour de nous et devant nous. La seule exigence que nous puissions faire valoir à son endroit (créatrice pour chaque individu des devoirs correspondants) est qu'elle se réalise sous des formes dont chacune soit une contribution à la plus grande générosité des autres.

\section{Lezama Lima, José: La expresión americana. Madrid: Alianza Editorial 1969,}

S. 91: De la persecución religiosa va a pasar a la persecución política, y estando en Londres, al tener noticias del alzamiento del cura Hidalgo, escribe folletos justificando el ideario separatista. Rodando por los calabozos, amigándose con el liberalismo de Jovellanos, combatiendo contra la invasión francesa, o desembarcando con los conjurados de Mina, al fin encuentra con la proclamación de la independencia de su país, la plenitud de su rebeldía, la forma que su madurez necesitaba para que su vida alcanzara el sentido de su proyección histórica. En Fray Servando, en esa transición del barroco al romanticismo, sorprendemos ocultas sorpresas muy americanas. Cree romper con la tradición, cuando la agranda. Así, cuando cree separarse de lo hispánico, lo reencuentra en él, agrandado.

S. 97: Fray Servando fue el primer escapado, con la necesaria fuerza para llegar al final que todo lo aclara, del señorío barroco, del señor que transcurre el voluptuoso diálogo con el paisaje. Fue el perseguido, que hace de la persecución un modo de integrarse.

S. 115 f.: Pero esa gran tradición romántica del siglo XIX, la del calabozo, la ausencia, la imagen y la muerte, logra crear el hecho americano, cuyo destino está más hecho de ausencias posibles que de presencias imposibles. La tradición de las ausencias posibles ha sido la gran tradición americana y donde se sitúa el hecho histórico que se ha logrado. José Martí representa, en una gran navidad verbal, la plenitud de la ausencia posible. En él culmina el calabozo de Fray Ser- 
vando, la frustración de Simón Rodríguez, la muerte de Francisco Miranda pero también el relámpago de las siete intuiciones de la cultura china, que le permite tocar, por la metáfora del conocimiento, y crear el remolino que lo destruye; el misterio que no fija la huida de los grandes perdedores y la oscilación entre dos grandes destinos, que él resuelve al unirse a la casa que va a ser incendiada. Su muerte tenemos que situarla dentro del Pachacámac incaico, del dios invisible.

S. 116 f.: José Martí representa, en una gran navidad verbal, la plenitud de la ausencia posible. En él culmina el calabozo de Fray Servando, la frustración de Simón Rodríguez, la muerte de Francisco Miranda pero también el relámpago de las siete intuiciones de la cultura china, que le permite tocar, por la metáfora del conocimiento, y crear el remolino que lo destruye [...] Las palabras finales de sus dos Diarios, nos recuerdan las precauciones, que se han de tomar por las moradas subterráneas según el Libro de los muertos. Pide libros, pide jarros con hojas de higo. Ofrece alimentos «con una piedra en el pilón para los recién venidos». El valle parece exornar sus gargantas para el recién venido, el cual comienza a reconocer y a nombrar, a orientarse en lo irreal, según los cultos órficos, por la gravedad del pan, el equilibrio de la escudilla de la leche y los ladridos del perro. Sus Diarios son el descubrimiento táctil del desembarcado, del reciénvenido, del duermevela, del entrevisto. Preside dos grandes momentos de la expresión americana. Aquel que crea un hecho por el espejo de la imagen. Y aquel que en la jácara mexicana, la anchurosa guitarra de Martín Fierro, la ballena teológica y el cuerpo whitmaniano, logra el retablo para la estrella que anuncia el acto naciente.

\section{Mármol, José: Amalia. Prologo de Trinidad Perez. La Habana: Casa de las}

Americas 1976, S. 126: «Tucumán es el jardín del universo en cuanto a la grandeza y sublimidad de su naturaleza», escribió el capitán Andrews en su Viaje a la América del Sur, publicado en Londres en 1827; y el viajero no se alejó mucho de la verdad con esa metáfora, al parecer tan hiperbólica. Todo cuanto sobre el aire y la tierra puede reunir la naturaleza tropical de gracias, de lujo y de poesía, se encuentra confundido allí, como si la provincia de Tucumán fuese la mansión escogida de los genios de esa desierta y salvaje tierra que se extiende desde el Estrecho hasta Bolivia, y desde los Andes al Uruguay. Suave, perfumada, fértil y rebosando gracias y opulencias de luz, de pájaros y flores, la naturaleza armoniza allí el espíritu de las criaturas con las impresiones y perspectivas poéticas en que se despierta y desenvuelve su vida.

S. 183 f.: ¿Queréis patria, queréis instituciones y libertad, vosotros que os llamáis herederos de los regeneradores de un mundo? Pues bien; recordad que ellos y la América toda fueron una asociación de hermanos durante la larga guerra de nuestra independencia, para lidiar con el enemigo común, y asociaos vosotros para lidiar contra el enemigo general de nuestra reforma social: la igno- 
rancia; contra el instigador de nuestras pasiones salvajes: el fanatismo político; contra el generador de nuestra desunión, de nuestros vicios, de nuestras pasiones rencorosas, de nuestro espíritu vanidoso y terco: el escepticismo religioso. Porque, creedme, nos faltan la religión, la virtud y la ilustración, y no tenemos de la civilización sino sus vicios. Durante ese discurso Daniel habíase levantado poco a poco de su asiento, y como arrebatados por la energía de sus palabras, todos los jóvenes habían hecho lo mismo. La última palabra se escapó de los labios del joven orador y los brazos de Eduardo lo estrecharon contra su corazón. Mirad, señores -dijo Belgrano, paseando sus ojos por la reunión de sus amigos, y conservando su brazo izquierdo sobre el hombro derecho de Daniel- mirad: mi semblante está bañado de lágrimas y los ojos que las vierten habían, con la niñez, perdido su recuerdo. ¿Las adivináis? No. La sensibilidad de todos vosotros está conmovida por las palabras de mi amigo y la mía lo está por el porvenir de nuestra patria. Yo creo en su regeneración, creo en su grandeza y en su futura gloria; pero esa asociación que las ha de germinar en el Plata no será, no, la obra de nuestra generación, ni de nuestros hijos; y mis lágrimas nacen de la terrible creencia que me domina de que no seré yo ni vosotros los que veamos levantado en el Plata la brillante aurora de nuestra libertad civilizada, porque nos faltan para eso naturaleza, hábitos y educación para formar esa asociación de hermanos que sólo la grandeza de la obra santa de nuestra independencia pudo inspirar en la generación de nuestros padres.

S. 253: Eran las cinco de una tarde fría y nebulosa, y al lado de la chimenea, sentado en un pequeño taburete a los pies de Amalia, Eduardo le traducía uno de los más bellos pasajes del Manfredo, de Byron; y Amalia, reclinado su brazo sobre el hombro de Eduardo y rozando con sus rizos de seda su alta y pálida frente, lo oía, enajenada, más por la voz que llegaba hasta su corazón, que por los bellos raptos de la imaginación del poeta; y de cuando en cuando, Eduardo levantaba su cabeza para buscar en los ojos de su Amalia un raudal mayor de poesía que el que brotaban los pensamientos del águila de los poetas del siglo XIX. Ella y él representaban allí el cuadro vivo y acabado de la felicidad más completa [...].

S. 291: Cuando en 1839 recibí, en la cárcel y en los grillos de Rosas, el bautismo cívico destinado por él a todos los argentinos que se negaban a prostituirse en el lupanar de sangre y vicios en que se revolcaban sus amigos, don Bernardo Victorica usó para conmigo ciertas atenciones que estaban absolutamente prohibidas. Sólo, sumido en un calabozo donde apenas entraba la luz del día por una pequeña claraboya, yo no olvidaré nunca el placer que sentí cuando el jefe de Policía consintió en que se me permitiese hacer traer algunas velas y algunos libros. Y fue sobre la llama de esas velas donde carbonicé algunos palitos de yerba mate para escribir con ellos, sobre las paredes de mi calabozo, los primeros versos contra Rosas, y los primeros juramentos de mi alma de diecinueve años de hacer 
contra el tirano y por la libertad de mi patria todo cuanto he hecho y sigo haciendo en el largo período de mi destierro.- MARMOL.

S. 384 f.: Tú me amas, ¿no es verdad? ¿Tú aceptas en el mundo mi destino, es verdad? Sí. ¿Cualquiera que sea? Sí, sí, cualquiera. ¡Ángel de mi alma! Si eres feliz, yo beberé en tu sonrisa la aventura inefable de los ángeles. ¡Amalia! Si eres desgraciado, yo compartiré tus pesares; y... ¿Y...? Acaba. Y si el destino adverso que te persigue te condujera a la muerte, el golpe que cortase tu vida haría volar mi espíritu en tu busca... Eduardo estrechó contra su corazón a aquella generosa criatura; y en ese instante, cuando ella acababa su última palabra inspirada por el rapto de entusiasmo en que se hallaba, un trueno lejano, prolongado, ronco, vibró en el espacio como el eco de un cañonazo en un país montañoso. La superstición es la compañera inseparable de los espíritus poéticos, y aquellos dos jóvenes, en ese momento embriagados de felicidad, se asieron de las manos y miráronse por algunos segundos con una expresión indefinible. Amalia al fin bajó su cabeza, como abrumada por alguna idea profética y terrible. [...] La tempestad está muy lejos, Amalia. Y entretanto, un cielo tan puro como tu alma sirve de velo sobre la frente de los dos. El Universo es nuestro templo, y es Dios el sacerdote santo que bendice el sentido amor de nuestras almas, desde esas nubes y desde esos astros; Dios mismo que los sostiene con el imán de su mirada, y entre ellos el nuestro..., sí..., aquélla..., aquélla debe ser la estrella de nuestra felicidad en la Tierra... ¿No la ves? Clara como tu alma, brillante como tus ojos, linda y graciosa como tú misma... ¿La ves, mi Amalia? No..., aquélla -contestó la joven extendiendo su brazo y señalando una pequeña y amortiguada estrella que parecía próxima a sumergirse en las ondas del poderoso Plata, tranquilo como toda la Naturaleza en ese instante.

Martí, José: A José Dolores Poyo. In (ders.): Obras Completas. La Habana: Editorial de Ciencias Sociales 1975, Bd. 3, S. 226: La única gloria verdadera del hombre, -si un poco de fama fuera cosa alguna en la composición de obra tan vasta como el mundo,-estaría en la suma de servicios que hubiese, por sobre su propia persona, prestado a los demás. [...] Yo ya no soy hombre sentado: nunca lo fui: menos, cuando empezamos a recoger la cosecha de nuestra paciencia y previsión: menos que nunca, hoy.

Martí, José: Asuntos para boletín (1875), in: ders.: Obras Completas. Bd. 6, S. 222: El género humano tiene montañas y llanuras, y así hablan las montañas de la tierra con las alturas de los cielos, como los genios entre los hombres con las altezas y las excelencias del espíritu. [...] Pero parece que, como la mano del hombre destruye las eminencias de la tierra, no sé qué mano oculta pone empeño en hacer obra igual con las del género humano;- y la inteligencia se vulgariza y 
se difunde por los abandonados llanos, y a la par que en lo común de las gentes se nota más sensatez en el juicio, más viveza en la comprensión, en útiles conocimientos más riqueza, escasean o se ocultan aquellas cumbres altas del talento, que antes reunían en un cerebro los destinos y el porvenir de una nación. Todo va diseminándose en justicia e igualdades; es buena hija de la libertad esta vulgarización y frecuencia del talento.

Martí, José: Prólogo al «Poema del Niágara», in: ders.: Obras Completas. Bd. 7, S. 228: Una gran montaña parece menor cuando está rodeada de colinas. Y ésta es la época en que las colinas se están encimando a las montañas; en que las cumbres se van deshaciendo en llanuras; época ya cercana de la otra en la que todas las llanuras serán cumbres. Con el descenso de las eminencias suben de nivel los llanos, lo que hará más fácil el tránsito por la tierra. Los genios individuales se señalan menos, porque les va faltando la pequeñez de los contornos que realzaban antes tanto su estatura. [...] Asístese como a una descentralización de la inteligencia. Ha entrado a ser lo bello dominio de todos. Suspende el número de buenos poetas secundarios y la escasez de poetas eminentes solitarios. El genio va pasando de individual a colectivo. El hombre pierde en beneficio de los hombres. Se diluyen, se expanden las cualidades de los privilegiados a la masa; lo que no placerá a los privilegiados de alma baja, pero sí a los de corazón gallardo y generoso, que saben que no es en la tierra, por grande criatura que se sea, más que arena de oro, que volverá a la fuente hermosa de oro, y reflejo de la mirada del Creador.

Marti, José: El hombre antiguo de América y sus artes primitivas. In (ders.): Obras Completas. Bd. 8, S. 334 f.: No con la hermosura de Tetzcontzingo, Copán y Quiriguá, no con la profusa riqueza de Uxmal y de Mitla, están labrados los dólmenes informes de la Galia; ni los ásperos dibujos en que cuentan sus viajes los noruegos; ni aquellas líneas vagas, indecisas, tímidas con que pintaban al hombre de las edades elementales los mismos iluminados pueblos del mediodía de Italia. ¿Qué es, sino cáliz abierto al sol por especial privilegio de la naturaleza, la inteligencia de los americanos? Unos pueblos buscan, como el germánico; otros construyen, como el sajón; otros entienden, como el francés; colorean otros, como el italiano; sólo al hombre de América es dable en tanto grado vestir como de ropa natural la idea segura de fácil, brillante y maravillosa pompa.

Martí, José: Nuestra América. Edición crítica. Investigación, presentación y notas Cintio Vitier. La Habana: Centro de Estudios Martianos - Casa de las Américas 1991, S. 13: Cree el aldeano vanidoso que el mundo entero es su aldea, y con tal que él quede de alcalde, o le mortifiquen al rival que le quitó la novia, o 
le crezcan en la alcancía los ahorros, ya da por bueno el orden universal, sin saber de los gigantes que llevan siete leguas en las botas, y le pueden poner la bota encima, ni de la pelea de los cometas en el cielo, que van por el aire dormido[s] engullendo mundos. Lo que quede de aldea en América ha de despertar. Estos tiempos no son para acostarse con el pañuelo a la cabeza, sino con las armas de almohada, como los varones de Juan de Castellanos: las armas del juicio, que vencen a las otras. Trincheras de ideas, valen más que trincheras de piedras.

S. 17 f.: Conocer es resolver. Conocer el país, y gobernarlo conforme al conocimiento, es el único modo de librarlo de tiranías. La universidad europea ha de ceder a la universidad americana. La historia de América, de los Incas a acá, ha de enseñarse al dedillo, aunque no se enseñe la de los arcontes de Grecia. Nuestra Grecia es preferible a la Grecia que no es nuestra. Nos es más necesaria. Los políticos nacionales han de reemplazar a los políticos exóticos. Injértese en nuestras repúblicas el mundo; pero el tronco ha de ser el de nuestras repúblicas. Y calle el pedante vencido; que no hay patria en que pueda tener el hombre más orgullo que en nuestras dolorosas repúblicas americanas.

S. 21: Éramos una visión, con el pecho de atleta, las manos de petimetre, y la frente de niño. Éramos una máscara, con los calzones de Inglaterra, el chaleco parisiense, el chaquetón de Norte-América y la montera de España. El indio, mudo, nos daba vueltas alrededor, y se iba al monte, a la cumbre del monte, a bautizar a sus hijos. el negro, oteado, cantaba en la noche la música de su corazón, solo y desconocido, entre las olas y las fieras. El campesino, el creador, se revolvía, ciego de indignación, contra la ciudad desdeñosa, contra su criatura.

S. 24 f.: Pensar es servir. Ni ha de suponerse, por antipatía de aldea, una maldad ingénita y fatal al pueblo rubio del continente, porque no habla nuestro idioma, ni ve la casa como nosotros la vemos, ni se nos parece en sus lacras políticas, que son diferentes de las nuestras; ni tiene en mucho a los hombres biliosos y trigueños, ni mira caritativo, desde su eminencia aún mal segura, a los que, con menos favor de la historia, suben a tramos heroicos la vía de las repúblicas: ni se han de esconder los datos patentes del problema que puede resolverse, para la paz de los siglos, con el estudio oportuno, -y la unión tácita y urgente del alma continental. ¡Porque ya suena el himno unánime; la generación real lleva a cuestas, por el camino abonado por los padres sublimes, la América trabajadora; del Bravo a Magallanes, sentado en el lomo del cóndor, regó el Gran Semí, por las naciones románticas del continente y por las islas dolorosas del mar, la semilla de la América nueva!

Mier, Fray Servando Teresa de: Memorias. Edición y prólogo de Antonio Castro Leal. México: Editorial Porrúa 1946, Bd. 1, S. 243: Como entonces fue cuando yo abrí los ojos para conocer la práctica de nuestro gobierno y el remedio 
de los americanos en las dos vías, reservada y del Consejo de Indias, para sus recursos e impetraciones, será bien que yo se los abra a mis paisanos, para que no se fíen absolutamente en que tienen justicia, cosa sólo valedera si media gran favor o mucho dinero, y procuren acá transigir sus pleitos como puedan, aunque sea a mala composición. Porque allá el poder es más absoluto, más venal es la corte y los tribunales, mayor el número de los necesitados, de los malévolos e intrigantes, los recursos más difíciles, por no decir imposible, para un pobre, y, en una palabra: allá no se trata de conciencia, sino de dinero y de política, que en la inteligencia y práctica de las cortes es precisamente lo inverso de lo moral.

Bd. II, S. 56 f.: Del plano de las ciudades nada hay en Europa que se pueda comparar a las ciudades de nuestra América ni de los Estados Unidos. Todas aquéllas parecen que fueron fundadas por un pueblo enemigo de las líneas rectas. Todas son calles y callejuelas tuertas, enredijos sin orden y sin apariencia. [...] En las grandes ciudades venden el plano de ellas en forma de librito, para dirigirse el forastero, con la noticia de cuanto contienen. Sólo en España no hay nada de todo esto. Y sería inútil, porque sólo el cura y el sacristán saben leer en los pueblos. Camina uno como bárbaro por país de bárbaros, temblando de los salteadores que salen a robar a los viajeros, y sólo siguen al coche tropas de mendigos y muchachos, pidiendo a gritos limosna.

Bd. II, S. 62: En Marsella vi las mujeres, a lo menos del común, con mantillas como en España, donde únicamente se usan. Vi también una colonia de catalanes, otra después en Gibraltar, y dondequiera que hay algo que pescar, allí se encuentran con este título. Vi también allí, como en una ciudad fundada por los griegos, a éstos por la primera vez, que van a comerciar. No usan medias, llevan una chaqueta o cotón, a manera de nuestros indios, llevan el pelo corto y una especie de bonete o gorro encarnado con su borlita. Las mujeres usan un túnico; son carirredondas y de ojos grandes. Ellas y ellos tienen el mismo colorido de nuestros indios.

Bd. II, S. 162: En ninguna parte de Europa tienen el empeño que las españolas por presentar a la vista los pechos, y las he llegado a ver en Madrid en el paseo público con ellos totalmente de fuera, y con anillos de oro en los pezones. Lo mismo que en los dedos de los pies, enteramente desnudos, como todo el brazo desde el hombro. Y ya que no pueden desnudar las piernas, llevan medias color de carne.

Bd. II, S. 187: Yo escribí a Tres Palacios quejándome de las blasfemias que el viajero había escrito contra el venerable obispo Casas, y de que absolutamente ignoraba la geografía de América. Tres Palacios envió la carta a Estala, diciéndole que así éramos todos los mexicanos, y que nos cargase la mano. Estala entonces copió contra la América y especialmente contra México todos los absurdos y desatinos de Paw [sic!] y sus secuaces Raynal, Robertson y Laharpe, como si no estu- 
viesen ya pulverizados por Valverde, Carli, Clavijero, Molina, Iturri, Madisson, etc. [...]Así van todas las cosas en España. Yo comencé a escribir contra el viajero, para poner en el diario, Cartas de Tulitas Cacaloxochitl Cihuapiltzin Mexica, o señorita mexicana, al viajero universal. [...] Pero el Viajero se tradujo en portugués, y luego ha servido de guía a la geografía inglesa de Guthrie, que ha copiado todos los dislates de Estala contra México. Así se perpetúan las injurias y los errores.

Bd. II, S. 205: Cuando llegué a decir que mi padre era gobernador y comandante general del Nuevo Reino de León, el alcalde volvió con sorpresa la cara, porque se me acusaba como religioso y era un fenómeno que fuese sujeto distinguido. Luego prosiguió a hacerme preguntas muy largas, y le respondí que daría cuenta de toda mi vida; y, como así lo hiciese, mandó al escribano anotar que yo mismo dictaba. Mi historia le pareció una novela, y seguramente fingida, porque nada cuadraba con la acusación de la orden real. Así volví a mi chinchero y a dormir sobre los ladrillos, sin otra ropa que mi mismo vestido, y por cabecera mi pañuelo de narices.

Bd. II, S. 232: A no ser un gachupín malignante se hubiera explicado conmigo, le hubiera mostrado mis breves líneas, instruídole de todo, y ahorrado a su Provincia el gasto de mi manutención. Pero ¿qué se le da a un gachupín de la Provincia de que es ahijastro? El negocio es perseguir al criollo [...]

\section{Ortiz, Fernando: Contrapunteo cubano del tabaco y el azúcar. Prólogo y Cro- nología: Julio Le Riverend. Caracas: Biblioteca Ayacucho 1978, S. 13 f.: Tabaco} y azúcar son ambos productos del reino vegetal que se cultivan, se elaboran, se mercan y al fin se consumen con gran deleite en bocas humanas. Además, en la producción tabacalera y en la azucarera pueden advertirse los mismos cuatro elementos: tierra, máquina, trabajo y dinero, cuyas variantes combinaciones constituyen su historia. Pero, desde su germen en la entraña de la tierra hasta su muerte por el consumo humano, tabaco y azúcar se conducen casi siempre de modo antitético. La caña de azúcar y el tabaco son todo contraste. Diríase que una rivalidad los anima y separa desde sus cunas. Una es planta gramínea y otra es planta solanácea. La una brota de retoño, el otro de simiente [...] La una tiene su riqueza en el tallo y no en sus hojas, las cuales se arrojan; el otro vale por su follaje, no por su tallo, que se desprecia. La caña de azúcar vive en el campo largos años, la mata de tabaco sólo breves meses. Aquélla busca la luz, éste la sombra; día y noche, sol y luna. Aquélla ama la lluvia caída del cielo; éste el ardor nacido de la tierra. A los canutos de la caña se les saca el zumo para el provecho; a las hojas del tabaco se les seca el jugo porque estorba. El azúcar llega a su destino humano por el agua que lo derrite, hecho un jarabe; el tabaco llega a él por el fuego que lo volatiliza, convertido en humo. Blanca es la una, moreno es el otro. Dulce y sin olor es el azúcar; amargo y con aroma es el tabaco. ¡Contraste siempre! Alimento y 
veneno, despertar y adormecer, energía y ensueño, placer de la carne y deleite del espíritu, sensualidad e ideación, apetito que se satisface e ilusión que se esfuma, calorías de vida y humaredas de fantasía, indistinción vulgarota y anónima desde la cuna e individualidad aristocrática y de marca en todo el mundo, medicina y magia, realidad y engaño, virtud y vicio. El azúcar es ella; el tabaco es él... La caña fue obra de los dioses, el tabaco lo fue de los demonios; ella es hija de Apolo, él es engendro de Proserpina...

S. 88: No hay, pues, para los versadores de Cuba, como habrá querido aquel arcipreste apicarado, una Pelea de Don Tabaco y Doña Azúcar, sino un mero discreteo que debiera acabar, como los cuentos de hadas, en casorio y felicidad. En la boda del tabaco con el azúcar. Y en el nacimiento del alcohol, concebido por obra y gracia del espíritu satánico, que es el mismo padre del tabaco, en la dulce entraña de la impurísima azúcar. Trinidad cubana: tabaco, azúcar y alcohol.

S. 96 f.: Entendemos que el vocablo transculturación expresa mejor las diferentes fases del proceso transitivo de una cultura a otra, porque éste no consiste solamente en adquirir una distinta cultura, que es lo que en rigor indica la voz anglo-americana aculturation, sino que el proceso implica también necesariamente la pérdida o desarraigo de una cultura precedente, lo que pudiera decirse una parcial desculturación, y, además, significa la consiguiente creación de nuevos fenómenos culturales que pudieran denominarse de neoculturación. Al fin, como bien sostiene la escuela de Malinowski, en todo abrazo de culturas sucede lo que en la cópula genética de los individuos: la criatura siempre tiene algo de ambos progenitores, pero también siempre es distinta de cada uno de los dos. En conjunto, el proceso es una transculturación, y este vocablo comprende todas las fases de su parábola.

Pauw, Cornelius de: Recherches philosophiques sur les Américains, ou Mémoires intéressants pour servir à l'Histoire de l'Espèce humaine. 2 Bde. Berlin: Chez Georges Jacques Decker, Imp. du Roi 1768-1769, hier Bd. I, S. a3v: Après le prompt massacre de quelques millions de Sauvages, l'atroce vainqueur se sentit atteint d'un mal épidémique, qui, en attaquant à la fois les principes de la vie \& les sources de la génération, devint bientôt le plus horrible fléau du monde habitable. L'homme déjà accablé du fardeau de son existence, trouva, pour comble d'infortune, les germes de la mort entre les bras du plaisir \& au sein de la jouissance : il se crut perdu sans ressource : il crut que la nature irritée avoit juré sa ruine.

Proust, Marcel: Journées de lecture. In (ders.): Pastiches et mélanges. Paris: Gallimard 1970, S. 209: Il n'y a peut-être pas de jours de notre enfance que nous ayons si pleinement vécus que ceux que nous avons cru laisser sans les vivre, ceux 
que nous avons passés avec un livre préféré. Tout ce qui, semblait-il, les remplissait pour les autres, et que nous écartions comme un obstacle vulgaire à un plaisir divin: le jeu pour lequel un ami venait nous chercher au passage le plus intéressant, l'abeille ou le rayon de soleil gênants qui nous forçaient à lever les yeux de la page ou à changer de place, les provisions de goûter qu'on nous avait fait emporter et que nous laissions à côté de nous sur le banc, sans y toucher, tandis que, au-dessus de notre tête, le soleil diminuait de force dans le ciel bleu, le dîner pour lequel il avait fallu rentrer et pendant lequel nous ne pensions qu'à monter finir, tout de suite après, le chapitre interrompu, tout cela, dont la lecture aurait dû nous empêcher de percevoir autre chose que l'importunité, elle en gravait au contraire en nous un souvenir tellement doux (tellement plus précieux à notre jugement actuel que ce que nous lisions alors avec amour) que, s'il nous arrive encore aujourd'hui de feuilleter ces livres d'autrefois, ce n'est plus que comme les seuls calendriers que nous ayons gardés des jours enfuis, et avec l'espoir de voir reflétés sur leurs pages les demeures et les étangs qui n'existent plus.

Rama, Angel: La formación de la novela latinoamericana. In (ders.): La novela en América Latina. Panoramas 1920-1980. Montevideo - Xalapa: Fundación Angel Rama -Universidad Veracruzana 1986, S. 21: El pícaro que inventa Lizardi no es sólo un arcaísmo temático, sino también formal. Restaura la originaria condición de la novela como arma de combate para destruir un orden establecido, apelando a la clásica argucia (única por lo demás que ese orden fue capaz de admitir) del hablar irresponsable del marginado social: el desheredado o el loco, Lázaro o Quijote. [...] A partir de ese arranque la novela latinoamericana no hará sino rehacer una historia conocida: la que cuenta las vicisitudes de la estrecha relación de un género con una clase social, que es a comienzos del xix la burguesía mercantil y funcionarial que ha de ser arrasada por la tormenta revolucionaria y por la posterior conmoción social pero a la que ha de caber, por una serie de sucesos casi azarosos, la conducción de los nuevos países independientes y la sujeción a sus normas de inmensas poblaciones heterogéneas que tardará más de medio siglo en embridar.

Raynal, Guillaume-Thomas: Histoire des deux Indes. Vol. 6, Livre 11. Genf: Pellet 1781, S. 134 f.: Vos esclaves n'ont besoin ni de votre générosité, ni de vos conseils, pour briser le joug sacrilège qui les opprime. La nature parle plus haut que la philosophie \& que l'intérêt. Déjà se sont établies deux colonies de nègres fugitifs, que les traités \& la force mettent à l'abri de vos attentats. Ces éclairs annoncent la foudre, \& il ne manque aux nègres qu'un chef assez courageux, pour les conduire à la vengeance \& au carnage. Où est-il, ce grand homme, que la nature doit à ses enfans vexés, opprimés, tourmentés ? Où est-il ? Il paroîtra, 
n'en doutons point, il se montrera, il lèvera l'étendard sacré de la liberté. Ce signal vénérable rassemblera autour de lui les compagnons de son infortune. Plus impétueux que les torrens, ils laisseront par-tout les traces ineffables de leur juste ressentiment. Espagnols, Portugais, Anglois, François, Hollandois, tous leurs tyrans deviendront la proie du fer \& de la flamme. Les champs Américains s'enivreront avec transport et d'un sang qu'ils attendoient depuis si long-tems, et les ossemens de tant d'infortunés entassés depuis trois siècles, tressailliront de joie. L'ancien monde joindra les applaudissemens au nouveau. Par-tout on bénira le nom du héros qui aura rétabli les droits de l'espèce humaine, par-tout on érigera des trophées à sa gloire. Alors disparaîtra le code noir ; \& que le code blanc sera terrible, si le vainqueur ne consulte que le droit de représailles ! En attendant cette révolution, les nègres gémissent sous le joug des travaux, dont la peinture ne peut que nous intéresser de plus en plus à leur destinée.

\section{Rizal, José: Noli me tangere Prólogo Leopoldo Zea. Edición y cronología} Margara Russotto. Caracas: Biblioteca Ayacucho 1976, S. 9: La casa a que aludimos es algo baja y de líneas no muy correctas: que el arquitecto que la haya construido no viera bien o que esto fuese efecto de los terremotos y huracanes, nadie puede decirlo con seguridad. Una ancha escalera de verdes balaustres y alfombrada a trechos conduce desde el zaguán o portal, enlosado de azulejos, al piso principal, entre macetas y tiestos de flores sobre pedestales de losa china de abigarrados colores y fantásticos dibujos.

Rodó, José Enrique: Ariel. Motivos de Proteo. Prólogo: Carlos Real de Azúa. Edición y Cronología Angel Rama. Caracas: Biblioteca Ayacucho 1976, S. 14 f.: En los testeros, esculpidas imágenes hablaban de idealidad, de ensimismamiento, de reposo... Y el viejo rey aseguraba que, aun cuando a nadie fuera dado acompañarle hasta allí, su hospitalidad seguía siendo en el misterioso seguro tan generosa y grande como siempre, sólo que los que él congregaba dentro de sus muros discretos eran convidados impalpables y huéspedes sutiles. En él soñaba, en él se libertaba de la realidad, el rey legendario; en él sus miradas se volvían a lo interior [...]; nadie lo profanó jamás, porque nadie hubiera osado poner la planta irreverente allí donde el viejo rey quiso estar solo con sus sueños y aislado en la última Thule de su alma. Yo doy al cuento el escenario de vuestro reino interior.

S. 28: Dentro de esa contemporánea literatura del norte, en la cual la preocupación por las altas cuestiones sociales es tan viva, surge a menudo la expresión de la misma idea, del mismo sentimiento; Ibsen desarrolla la altiva arenga de su Stockmann alrededor de la afirmación de que "las mayorías compactas son el enemigo más peligroso de la libertad y la verdad”; y el formidable Nietzsche 
opone al ideal de una humanidad mediatizada la apoteosis de las almas que se yerguen sobre el nivel de la humanidad como una viva marea.-

S. 51: ¿No la veréis vosotros, la América que nosotros soñamos; hospitalaria para las cosas del espíritu, y no tan sólo para las muchedumbres que se amparen a ella; pensadora, sin menoscabo de su aptitud para la acción; serena y firme a pesar de sus entusiasmos generosos; resplandeciente con el encanto de una seriedad temprana y suave, como la que realza la expresión de un rostro infantil cuando en él se revela, al través de la gracia intacta que fulgura, el pensamiento inquieto que despierta?... -

S. 55: Así habló Próspero. - Los jóvenes discípulos se separaron del maestro después de haber estrechado su mano con afecto filial. De su suave palabra, iba con ellos la persistente vibración en que se prolonga el lamento del cristal herido, en un ambiente sereno. Era la última hora de la tarde. Un rayo del moribundo sol atravesaba la estancia, en medio de discreta penumbra, $\mathrm{y}$, tocando la frente de bronce de la estatua, parecía animar en los altivos ojos de Ariel la chispa inquieta de la vida. Prolongándose luego, el rayo hacía pensar en una larga mirada que el genio, prisionero en el bronce, enviase sobre el grupo juvenil que se alejaba. -

Rousseau, Jean-Jacques: Les Confessions. Paris: Launette 1889, Bd. I, S. 1f.: Je forme une entreprise qui n'eut jamais d'exemple et dont l'exécution n'aura point d'imitateur. Je veux montrer à mes semblables un homme dans toute la vérité de la nature ; et cet homme ce sera moi. Moi seul. Je sens mon cœur et je connais les hommes. Je ne suis fait comme aucun de ceux que j'ai vus ; j'ose croire n'être fait comme aucun de ceux qui existent. Si je ne vaux pas mieux, au moins je suis autre. Si la nature a bien ou mal fait de briser le moule dans lequel elle m'a jeté, c'est ce dont on ne peut juger qu'après m'avoir lu. Que la trompette du jugement dernier sonne quand elle voudra ; je viendrai, ce livre à la main, me présenter devant le souverain juge. Je dirai hautement : voilà ce que j'ai fait, ce que j'ai pensé, ce que je fus. J'ai dit le bien et le mal avec la même franchise. Je n'ai rien tu de mauvais, rien ajouté de bon, et s’il m'est arrivé d'employer quelque ornement indifférent, ce n'a jamais été que pour remplir un vide occasionné par mon défaut de mémoire ; j'ai pu supposer vrai ce que je savais avoir pu l'être, jamais ce que je savais être faux. Je me suis montré tel que je fus, méprisable et vil quand je l'ai été, bon, généreux, sublime, quand je l'ai été : j'ai dévoilé mon intérieur tel que tu l'as vu toi-même. Etre éternel, rassemble autour de moi l'innombrable foule de mes semblables ; qu'ils écoutent mes confessions, qu'ils gémissent de mes indignités, qu'ils rougissent de mes misères. Que chacun d'eux découvre à son tour son cœur aux pieds de ton trône avec la même sincérité ; et puis qu'un seul te dise, s'il l'ose : Je fus meilleur que cet homme-là. 
Rousseau, Jean-Jacques: Discours sur l'origine et les fondements de l'inégalité parmi les hommes. In (ders.): Euvres complètes. Bd. III. Edition publiée sous la direction de Bernard Gagnebin et Marcel Raymond avec, pour ce volume, la collaboration de François Bouchardy, Jean-Daniel Candaux, Robert Derathé, Jean Fabre, Jean Starobinski et Sven Stelling-Michaud. Paris: Gallimard 1975, S. 213: Les Académiciens qui ont parcouru les parties Septentrionales de l'Europe et Méridionales de l'Amérique, avoient plus pour objet de les visiter en Géomètres qu'en Philosophes. Cependant, comme ils étoient à la fois l'un et l'autre, on ne peut pas regarder comme tout à fait inconnues les régions qui ont été vues et décrites par les La Condamine et les Maupertuis. [...] A ces relations près, nous ne connoissons point les Peuples des Indes Orientales, fréquentées uniquement par des Européens plus curieux de remplir leurs bourses que leurs têtes. [..] toute la terre est couverte de Nations dont nous ne connoissons que les noms, et nous nous mêlons de juger le genre- humain! Supposons un Montesquieu, un Buffon, un Diderot, un Duclos, un d'Alembert, un Condillac, ou des hommes de cette trempe voyageant pour instruire leurs compatriotes, observant et décrivant comme ils savent faire, la Turquie, l'Égypte, la Barbarie, l'Empire de Maroc, la Guinée, les pays des Caffres, l'intérieur de l’Afrique et ses côtes Orientales [...]: puis dans l'autre Hémisphère le Mexique, le Pérou, le Chili, les Terres magellaniques, sans oublier les Patagons vrais ou faux [...]; supposons que ces nouveaux Hercules, de retour de ces courses mémorables, fissent ensuite à loisir l'Histoire naturelle, Morale et Politique de ce qu'ils auroient $v u$, nous verrions nous mêmes sortir un monde nouveau de dessous leur plume, et nous apprendrions ainsi à connoître le nôtre.

Saint-Pierre, Bernardin de: Harmonies de la Nature. Bd. III. Paris: Chez Méquignon-Marvis 1818, S. 385 f.: Cependant tous ces corps planétaires n'offrent point à leurs spectateurs des points de vue isolés et toujours permanens; ils voient le double anneau, de plus de neuf mille cinq cents lieues de largeur, avec tous ses continens, toutes ses mers, toutes ses montagnes, ses îles et ses fleuves, et sa circonférence de plus de deux cent mille lieues, passer sous leurs yeux en dix heures de temps. Leur ravissement est mille fois plus grand que celui d'un homme qui, n'étant jamais sorti de son village, lit pour la première fois une relation de voyage à la Mer du Sud, et qui, dans quelques heures, fait en esprit le tour du monde. Ils doivent voir sur les deux faces de leur anneau, des effets qui existent sur les deux hémisphères de notre globe, et que l'œil humain ne peut saisir à la fois ; ils doivent y voir encore deux atmosphères, l'une supérieure, l'autre inférieure, et des îles et des chaînes de montagnes adossées par leurs bases. S’ils ont un Herschell, ils doivent distinguer dans des terres si voisines, des rivières, des troupeaux, des forêts, des amans et des amantes opposés par leurs pieds, et qui se 
donnent les mains aux extrémités de leur anneau [...]. Des bergers et des bergères qui dansent en rond autour d'un mai qu'ils ont planté, ou de jeunes garçons et de jeunes filles qui sautent de joie autour d'une grande meule de blé qu'ils ont moissonné, n’ont point de mouvemens aussi variés et aussi gracieux que ces reines de nuits autour du globe qu'elles éclairent et qu'elles fécondent.

\section{Saint-Pierre, Bernardin de: Paul et Virginie. Edition revue et augmentée d'une chronologie. Paris: Editions Garnier Frères 1964, S. 57-60: Mais les} femmes ont contribué plus que les philosophes à former et à réformer les nations. Elles ne pâlirent point les nuits à composer de longs traités de morale ; elles ne montèrent point dans des tribunes pour faire tonner les lois. Ce fut dans leurs bras qu'elles firent goûter aux hommes le bonheur d'être tour à tour, dans le cercle de la vie, enfants heureux, amants fidèles, époux constants, pères vertueux. Elles posèrent les premières bases des lois naturelles. La première fondatrice d'une société humaine fut une mère de famille. [...] Elles sont les premiers et les derniers apôtres de tout culte religieux qu'elles leur inspirent, dès la plus tendre enfance. Elles embellissent tout le cours de leur vie. [...] Elles inventèrent le pain, les boissons agréables, les tissus des vêtements, les filatures, les toiles, etc. [...] Elles imaginèrent pour plaire aux hommes les chansons gaies, les danses innocentes, et inspirèrent à leur tour la poésie, la peinture, la sculpture, l'architecture, à ceux d'entre eux qui désirèrent conserver d'elles de précieux ressouvenirs. [...] En effet, tout objet aimable a sa vénusté, c'est-à-dire une portion de cette beauté ineffable qui engendre les amours. La plus touchante en est sans doute la sensibilité, cette âme de l'âme qui en anime toutes les facultés. Ce fut par elle que Vénus subjugua le dieu indomptable de la guerre.

S. 154 f.: Je dis à Paul : «Mon ami, votre sœur restera. Demain nous en parlerons au gouverneur : laissez reposer votre famille, et venez passer cette nuit chez moi. Il est tard, il est minuit ; La croix du sud est droite sur l'horizon.» Il se laissa emmener sans rien dire, et après une nuit forte agitée, il se leva au point du jour, et s'en retourna à son habitation. «Mais qu'est-il besoin de vous continuer plus longtemps le récit de cette histoire? Il n'y a jamais qu'un côté agréable à connaître dans la vie humaine. Semblable au globe sur lequel nous tournons, notre révolution rapide n'est que d'un jour, et une partie de ce jour ne peut recevoir la lumière que l'autre ne soit livrée aux ténèbres.» «Mon père, lui dis-je, je vous en conjure, achevez de me raconter ce que vous avez commencé d'une manière si touchante. Les images du bonheur nous plaisent, mais celles du malheur nous instruisent. Que devint, je vous prie, l'infortuné Paul?» - «Le premier objet que vit Paul, en retournant à l'habitation, fut la négresse Marie, qui, montée sur un rocher, regardait vers la pleine mer. Il lui cria du plus loin qu'il l'aperçut : «Où est Virginie?» Marie tourna la tête vers son jeune maître, et se mit à pleurer. Paul, hors de lui, 
revint sur ses pas, et courut au port. Il y apprit que Virginie s'était embarquée au point du jour, que son vaisseau avait mis à la voile aussitôt, et qu'on ne le voyait plus. Il revint à l'habitation, qu'il traversa sans parler à personne.»

S. 202 f.: A peine ce jeune homme avait-il repris l'usage de ses sens, qu'il se relevait et retournait avec une nouvelle ardeur vers le vaisseau, que la mer cependant entrouvrait par d'horribles secousses. Tout l'équipage, désespérant alors de son salut, se précipitait en foule à la mer, sur des vergues, des planches, des cages à poules, des tables, et des tonneaux. On vit alors un objet digne d'une éternelle pitié: une jeune demoiselle parut dans la galerie de la poupe du Saint-Géran, tendant les bras vers celui qui faisait tant d'efforts pour la joindre. C'était Virginie. Elle avait reconnu son amant à son intrépidité. La vue de cette aimable personne, exposée à un si terrible danger, nous remplit de douleur et de désespoir. Pour Virginie, d'un port noble et assuré, elle nous faisait signe de la main, comme nous disant un éternel adieu. Tous les matelots s'étaient jetés à la mer. Il n'en restait plus qu'un sur le pont, qui était tout nu et nerveux comme Hercule. Il s'approcha de Virginie avec respect : nous le vîmes se jeter à ses genoux, et s'efforcer même de lui ôter ses habits; mais elle, le repoussant avec dignité, détourna de lui sa vue. On entendit aussitôt ces cris redoublés des spectateurs : «Sauvez-la, sauvez-la ; ne la quittez pas!» Mais dans ce moment une montagne d'eau d'une effroyable grandeur s'engouffra entre l'île d'Ambre et la côte, et s'avança en rugissant vers le vaisseau, qu'elle menaçait de ses flancs noirs et de ses sommets écumants. A cette terrible vue, le matelot s'élança seul à la mer ; et Virginie, voyant la mort inévitable, posa une main sur ses habits, l'autre sur son cœur, et levant en haut des yeux sereins, parut un ange qui prend son vol vers les cieux.

\section{Saint-Pierre, Bernardin de: Voyage à l'île de France. Un officier du Roi à l'île} Maurice, 1768-1770. Introduction et notes d'Yves Bénot. Paris: La Découverte - Maspéro 1983, S. 149 f.: Je pris mon parti. Je résolus de monter à travers les bois, quoique je ne visse aucune espèce de chemin. Me voilà donc à gravir dans les roches, tantôt me tenant aux arbres, tantôt soutenu par mon Noir qui marchait derrière moi. Je n'avais pas marché une demi-heure que la nuit vint : alors je n’eus plus d'autre guide que la pente même de la montagne. Il ne faisait point de vent, l'air était chaud ; je ne saurais vous dire ce que je souffris de la soif et de la fatigue. Plusieurs fois je me couchai, résolu d'en rester là. Enfin, après des peines incroyables, je m'aperçus que je cessais de monter ; bientôt après je sentis au visage une fraîcheur de vent de sud-est, et je vis au loin des feux dans la campagne. Le côté que je quittais était couvert d'une obscurité profonde. Je descendis en me laissant souvent glisser malgré moi. Je me guidai au bruit d'un ruisseau où je parvins enfin tout brisé. Quoique tout en sueur, je bus à discrétion et ayant senti de l'herbe sous ma main, je trouvai, pour surcroît de bonheur, que c'était du cresson, dont je 
dévorai plusieurs poignées. Je continuai ma marche vers le feu que j’apercevais, ayant la précaution de tenir mes pistolets armés, dans la crainte que ce ne fût une assemblée des Noirs marrons : c'était un défriché dont plusieurs troncs d'arbres étaient en feu. Je n'y trouvai personne.

S. 258: Je préférerais de toutes les campagnes celles de mon pays, non pas parce qu'elle est belle, mais parce que j'y ai été élevé. Il est dans le lieu natal un attrait caché, je ne sais quoi d'attendrissant qu'aucune fortune ne saurait donner et qu'aucun pays ne peut rendre. Où sont ces jeux du premier âge, ces jours si pleins sans prévoyance et sans amertume? La prise d'un oiseau me comblait de joie. [...] Mais la vie n'est qu'un petit voyage, et l'âge de l'homme un jour rapide. J'en veux oublier les orages pour ne me ressouvenir que des services, des vertus et de la constance de mes amis. Peut-être ces lettres conserveront leurs noms et les feront survivre à ma reconnaissance ! Peut-être iront-elles jusqu'à vous, bons Hollandais du Cap ! Pour toi, Nègre infortuné qui pleure sur les rochers de Maurice, si ma main, qui ne peut essuyer tes larmes, en fait verser de regret et de repentir à tes tyrans, je n'ai plus rien à demander aux Indes, j'y ai fait fortune.

\section{Sarmiento, Domingo Faustino: Facundo o Civilización y Barbarie. Mexico,} D.F.: SEP/UNAM 1982, S. 40: En la República Argentina se ven a un tiempo dos civilizaciones distintas en un mismo suelo: una naciente, que, sin conocimiento de lo que tiene sobre su cabeza, está remedando los esfuerzos ingenuos y populares de la Edad Media; otra que, sin cuidarse de lo que tiene a sus pies, intenta realizar los últimos resultados de la civilización europea. El siglo XIX y el siglo XII viven juntos: el uno dentro de las ciudades, el otro en las campañas.

S. 74: En efecto, sus amigos habían visto el rastro del tigre y corrían sin esperanza de salvarlo. El desparramo de la montura les reveló el lugar de la escena, y volar a él, desenrollar sus lazos, echarlos sobre el tigre, empacado y ciego de furor, fue la obra de un segundo. La fiera, estirada a dos lazos, no pudo escapar a las puñaladas repetidas con que en venganza de su prolongada agonía le traspasó el que iba a ser su víctima. «Entonces supe lo que era tener miedo»-decía el general don Juan Facundo Quiroga, contando a un grupo de oficiales este suceso. También a él le llamaron Tigre de los Llanos, y no le sentaba mal esta denominación, a fe.

S. 204 ff.: Es Tucumán un país tropical, en donde la Naturaleza ha hecho ostentación de sus más pomposas galas; es el Edén de la América, sin rival en toda la redondez de la tierra. Imaginaos los Andes cubiertos de un manto verdinegro de vegetación colosal, dejando escapar por debajo de la orla de este vestido doce ríos que corren a distancias iguales en dirección paralela hasta que empiezan a inclinarse todos hacia un rumbo y forman, reunidos, un canal navegable que se aventura en el corazón de la América. [...] Sobre toda esta vegetación, que ago- 
taría la paleta fantástica en combinaciones y riqueza de colorido, revolteaban enjambres de mariposas doradas, esmaltados picaflores, millones de loros color de esmeralda, urracas azules y tucanes anaranjados. El estrépito de esas aves vocingleras os aturde todo el día, cual si fuera el ruido de una canora catarata. [...] ¿Creéis, por ventura, que esta descripción es plagiada de Las mil y una noches $\mathrm{u}$ otros cuentos de hadas a la oriental!? Daos prisa más bien a imaginaros lo que no digo de la voluptuosidad y belleza de las mujeres que nacen bajo un cielo de fuego, y que, desfallecidas, van a la siesta a reclinarse muellemente bajo la sombra de los mirtos y laureles, a dormirse, embriagadas por las esencias que ahogan al que no está habituado a aquella atmósfera. [...] Los sollozos se escapan de entre la escogida y tímida comitiva; la sonrisa de la esperanza brilla en algunos semblantes, y todas las seducciones delicadas de la mujer son puestas en requisición para lograr el piadoso fin que se han propuesto. Facundo está vivamente interesado, y por entre la espesura de su barba negra alcanza a discernirse en las facciones la complacencia y el contento. Pero necesita interrogarlas una a una, conocer sus familias, la casa donde viven, mil pormenores que parecen entretenerlo y agradarle, y que ocupan una hora de tiempo, mantienen la expectación y la esperanza; al fin les dice con la mayor bondad: «¿No oyen ustedes esas descargas?»

S. 326: A fines del año 1840 salía yo de mi patria, desterrado por lástima, estropeado, lleno de cardenales, puntazos y golpes recibidos el día anterior en una de esas bacanales sangrientas de soldadesca y mazorqueros. Al pasar por los baños de Zonda, bajo las armas de la patria que en días más alegres había pintado en una sala, escribí con carbón estas palabras: On ne tue point les idées. El gobierno, a quien se comunicó el hecho, mandó una comisión encargada de descifrar el jeroglífico, que se decía contener desahogos innobles, insultos y amenazas. Oída la traducción, «iy bien! -dijeron-, ¿qué significa esto?...» Significaba simplemente que venía a Chile, donde la libertad brillaba aún, y que me proponía hacer proyectar los rayos de las luces de su prensa hasta el otro lado de los Andes. Los que conocen mi conducta en Chile saben si he cumplido aquella protesta.

S. 327: ¡Sombra terrible de Facundo, voy a evocarte para que, sacudiendo el ensangrentado polvo que cubre tus cenizas, te levantes a explicarnos la vida secreta y las convulsiones internas que desgarran las entrañas de un noble pueblo! Tú posees el secreto: ¡revélanoslo! Diez años aun después de tu trágica muerte, el hombre de las ciudades y el gaucho de los llanos argentinos, al tomar diversos senderos en el desierto decían: «¡No!; ¡no ha muerto! ¡Vive aún! ¡El vendrá!» ¡Cierto! Facundo no ha muerto; está vivo en las tradiciones populares, en la política y revoluciones argentinas; en Rosas, su heredero, su complemento; su alma ha pasado a este otro molde más acabado, más perfecto y lo que en él era sólo instinto, iniciación, tendencia, convirtióse en Rosas en sistema, en efecto y 
fin. La naturaleza campestre, colonial y bárbara, cambióse en esta metamorfosis en arte, en sistema y en política regular capaz de presentarse a la faz del mundo como el modo de ser un pueblo encarnado en un hombre que ha aspirado a tomar los aires de un genio que domina los acontecimientos, los hombres y las cosas. Facundo, provinciano, bárbaro, valiente, audaz, fue reemplazado por Rosas, hijo de la culta Buenos Aires, sin serlo él [...].

S. 330: Entonces se habría podido aclarar un poco el problema de la España, esa rezagada de Europa que, echada entre el Mediterráneo y el Océano, entre la Edad Media y el siglo XIX, unida a la Europa culta por un ancho istmo y separada del África bárbara por un angosto estrecho, está balanceándose entre dos fuerzas opuestas, ya levantándose en la balanza de los pueblos libres, ya cayendo en la de los despotizados; ya impía, ya fanática, ora despótica imprudente; maldiciendo sus cadenas rotas a veces, ya cruzando los brazos y pidiendo a gritos que le imponga el yugo que parece ser su condición y su modo de existir.

Sartre, Jean-Paul: Qu'est-ce que la littérature? Paris: Gallimard 1947, S. 143 u.152: Le XVIIIe siècle reste la chance, unique dans l'histoire, et le paradis bientôt perdu des écrivains français. Leur condition sociale n’a pas changé : originaires, à peu d'exceptions près, de la classe bourgeoise, les faveurs des grands les déclassent. Le cercle de leurs lecteurs réels s'est sensiblement élargi, parce que la bourgeoisie s'est mise à lire, mais les classes «inférieures» les ignorent toujours [...]. Mais, à la veille de la Révolution, [l'écrivain] jouit de cette chance extraordinaire qu'il lui suffit de défendre son métier pour servir de guide aux aspirations de la classe montante. Il le sait. Il se considère comme un guide et un chef spirituel, il prend ses risques. [...] Au temps des encyclopédistes, il ne s'agit plus de libérer l'honnête homme de ses passions en les lui reflétant sans complaisance, mais de contribuer par sa plume à la libération politique de l'homme tout court.

\section{Staël, Germaine de: De l'Allemagne [1810]. Paris: Librairie Stéréotype 1814,}

Bd. 1, S. 1f.: On peut rapporter l'origine des principales nations de l'Europe à trois grandes races différentes: la race latine, la race germanique, et la race esclavonne. Les Italiens, les Français, les Espagnols ont reçu des Romains leur civilisation et leur langage; les Allemands, les Suisses, les Anglais, les Suédois, les Danois et les Hollandais sont des peuples teutoniques; enfin, parmi les Esclavons, les Polonais et les Russes occupent le premier rang. Les nations dont la culture intellectuelle est d'origine latine sont plus anciennement civilisées que les autres; elles ont pour la plupart hérité de l'habile sagacité des Romains dans le maniement des affaires de ce monde. Des institutions sociales, fondées sur la religion païenne, ont précédé chez elles l'établissement du christianisme; et quand les peuples du nord sont venus les conquérir, ces peuples ont adopté, à beaucoup d'égards, les 
mœurs du pays dont ils étaient les vainqueurs. Ces observations doivent sans doute être modifiées d'après les climats, les gouvernements et les faits de chaque histoire.

Bd. 1, S. 16: Comme il n'existe point de capitale où se rassemble la bonne compagnie de toute l'Allemagne, l'esprit de société y exerce peu de pouvoir; l'empire du goût et l'arme du ridicule y sont sans influence. La plupart des écrivains et des penseurs travaillent dans la solitude, ou seulement entourés d'un petit cercle qu'ils dominent. Ils se laissent aller, chacun séparément, à tout ce que leur inspire une imagination sans contrainte; et si l'on peut apercevoir quelques traces de l'ascendant de la mode en Allemagne, c'est par le désir que chacun éprouve de se montrer tout à fait différent des autres. En France, au contraire, chacun aspire à mériter ce que Montesquieu disait de Voltaire: Il a plus que personne l'esprit que tout le monde $a$. Les écrivains allemands imiteraient plus volontiers encore les étrangers que leurs compatriotes. En littérature, comme en politique, les Allemands ont trop de considération pour les étrangers et pas assez de préjugés nationaux. C'est une qualité dans les individus que l'abnégation de soi-même et l'estime des autres; mais le patriotisme des nations doit être égoïste. [...] Les Allemands sont Saxons, Prussiens, Bavarois, Autrichiens; mais le caractère germanique, sur lequel devrait se fonder la force de tous, est morcelé comme la terre même qui a tant de différents maîtres.

Bd. 1, S. 153 f.: Tout le nord de l'Allemagne est rempli d'universités les plus savantes de l'Europe. Dans aucun pays, pas même en Angleterre, il n'y a autant de moyens de s'instruire et de perfectionner ses facultés. A quoi tient donc que la nation manque d'énergie, et qu'elle paraisse en général lourde et bornée, quoiqu'elle renferme un petit nombre d'hommes peut-être les plus spirituels de l'Europe? [...] En Allemagne, le génie philosophique va plus loin que partout ailleurs, rien ne l'arrête, et l'absence même de carrière politique, si funeste à la masse, donne encore plus de liberté aux penseurs. Mais une distance immense sépare les esprits du premier et du second ordre, parce qu'il n'y a point d'intérêt, ni d'objet d'activité, pour les hommes qui ne s'élèvent pas à la hauteur des conceptions les plus vastes. Celui qui ne s'occupe pas de l'univers, en Allemagne, n'a vraiment rien à faire.

Bd. 3, S. 53 f.: La philosophie spéculative a toujours trouvé beaucoup de partisans parmi les nations germaniques, et la philosophie expérimentale parmi les nations latines. Les Romains, très habiles dans les affaires de la vie, n'étaient point métaphysiciens [...]. L'influence de Rome ne s'exerça pas sur les peuples septentrionaux. Ils ont été civilisés presque en entier par le christianisme, et leur antique religion qui contenait en elle les principes de la chevalerie ne ressemblait en rien au paganisme du Midi. Il y avait un esprit de dévouement héroïque et généreux, un enthousiasme pour les femmes, qui faisait de l'amour un noble culte, enfin la 
rigueur du climat empêchant l'homme de se plonger dans les délices de la nature, il en goûtait d'autant mieux les plaisirs de l'âme.

Bd. 3, S. $\mathbf{3 7 6}$ ff.: Non seulement la nature se répète elle-même, mais elle semble vouloir imiter les ouvrages des hommes et leur donner ainsi un témoignage singulier de sa correspondance avec eux. [...] Souvent à l'aspect d'une belle contrée on est tenté de croire qu'elle a pour unique but d'exciter en nous des sentiments élevés et nobles. Je ne sais quel rapport existe entre les cieux et la fierté du cœur, entre les rayons de la lune qui reposent sur la montagne et le calme de la conscience, mais ces objets nous parlent un beau langage, et l'on peut s'abandonner au tressaillement qu'ils causent, l'âme s'en trouvera bien. [...] Ah! Quel enseignement que les horreurs de la destruction acharnée ainsi sur la race humaine! N'est-ce pas pour annoncer à l'homme que sa vie est ailleurs? La nature l'humilierait-elle à ce point si la divinité ne voulait pas le relever? Les vraies causes finales de la nature ce sont ses rapports avec notre âme et avec notre sort immortel; les objets physiques eux-mêmes ont une destination qui ne se borne point à la courte existence de l'homme ici-bas; ils sont là pour concourir au développement de nos pensées, à l'œuvre de notre vie morale. Les phénomènes de la nature ne doivent pas être compris seulement d'après les lois de la matière, quelque bien combinées qu'elles soient; ils ont un sens philosophique et un but religieux, dont la contemplation la plus attentive ne pourra jamais connaître toute l'étendue.

Staël, Germaine de: De la littérature: considéré dans ses rapports avec les institutions sociales. Paris: InfoMédia Communications 1998, S. 15: Je me suis proposé d'examiner quelle est l'influence de la religion, des mœurs et des lois sur la littérature, et quelle est l'influence de la littérature sur la religion, les mœurs et les lois. Il existe, dans la langue française, sur l'art d'écrire et sur les principes du goût, des traités qui ne laissent rien à désirer; mais il me semble qu'on n’a pas suffisamment analysé les causes morales et politiques, qui modifient l'esprit de la littérature. Il me semble qu'on n'a pas encore considéré comment les facultés humaines se sont graduellement développées par les ouvrages illustres en tout genre, qui ont été composés depuis Homère jusqu'à nos jours.

\section{Tocqueville, Alexis de: De la démocratie en Amérique. Paris: Pagnerre 1848,}

Bd. I, S. 8: Pense-t-on qu'après avoir détruit la féodalité et vaincu les rois, la démocratie reculera devant les bourgeois et les riches ? S’arrêtera-t-elle maintenant qu'elle est devenue si forte et ses adversaires si faibles ? Où allons-nous donc? Nul ne saurait le dire ; car déjà les termes de comparaison nous manquent : les conditions sont plus égales de nos jours parmi les chrétiens, qu'elles ne l'ont jamais été dans aucun temps ni dans aucun pays du monde ; ainsi la grandeur de ce qui est déjà fait empêche de prévoir ce qui peut se faire encore. [...] Il n'est 
pas nécessaire que Dieu parle lui-même pour que nous découvrions des signes certains de sa volonté ; il suffit d'examiner quelle est la marche habituelle de la nature et la tendance continue des événements; [...].

Bd. III, S. 63 f.: A mesure que les castes disparaissent, que les classes se rapprochent, que les hommes se mêlant tumultueusement, les usages, les coutumes, les lois varient, qu'il survient des faits nouveaux, que des vérités nouvelles sont mises en lumière, que d'anciennes opinions disparaissent et que d'autres prennent leur place, l'image d'une perfection idéale et toujours fugitive se présente à l'esprit humain. De continuels changements se passent alors à chaque instant sous les yeux de chaque homme. Les uns empirent sa position, et il ne comprend que trop bien qu'un peuple, ou qu'un individu, quelque éclairé qu'il soit, n'est point infaillible. Les autres améliorent son sort, et il en conclut que l'homme, en général, est doué de la faculté indéfinie de perfectionner. Ses revers lui font voir que nul ne peut se flatter d'avoir découvert le bien absolu; ses succès l'enflamment à le poursuivre sans relâche. Ainsi, toujours cherchant, tombant, se redressant, souvent déçu, jamais découragé, il tend incessamment vers cette grandeur immense qu'il entrevoit confusément au bout de la longue carrière que l'humanité doit encore parcourir. On ne saurait croire combien de faits découlent naturellement de cette théorie philosophique suivant laquelle l'homme est indéfiniment perfectible, et l'influence prodigieuse qu'elle exerce sur ceux mêmes qui, ne s'étant jamais occupés que d'agir et non de penser, semblent y conformer leurs actions sans la connaître.

Bd. III, S. 68 f.: Les Américains sont un peuple très ancien et très éclairé, qui a rencontré un pays nouveau et immense dans lequel il peut s'étendre à volonté, et qu'il féconde sans peine. Cela est sans exemple dans le monde. En Amérique, chacun trouve donc des facilités inconnues ailleurs pour faire sa fortune ou pour l'accroître. La cupidité y est toujours en haleine, et l'esprit humain, distrait à tout moment des plaisirs de l'imagination et des travaux de l'intelligence, n'y est entraîné qu'à la poursuite de la richesse. Non seulement on voit aux Etats-Unis, comme dans tous les autres pays, des classes industrielles et commerçantes; mais, ce qui ne s'était jamais rencontré, tous les hommes s'y occupent à la fois d'industrie et de commerce.

Bd. III, S. 70 f.: Je ne puis consentir à séparer l’Amérique de l'Europe, malgré l'Océan qui les divise. Je considère le peuple des Etats-Unis comme la portion du peuple anglais chargée d'exploiter les forêts du nouveau monde, tandis que le reste de la nation, pourvu de plus de loisirs et moins préoccupé des soins matériels de la vie, peut se livrer à la pensée et développer en tous sens l'esprit humain. La situation des Américains est donc entièrement exceptionnelle, et il est à croire qu'aucun peuple démocratique n'y sera jamais placé. Leur origine toute puritaine, leurs habitudes uniquement commerciales, le pays même qu'ils habitent et qui 
semble détourner leur intelligence de l'étude des sciences, des lettres et des arts; le voisinage de l'Europe, qui leur permet de ne point les étudier sans retomber dans la barbarie; mille causes particulières, dont je n'ai pu faire connaître que les principales, ont dû concentrer d'une manière singulière l'esprit américain dans le soin des choses purement matériels. Les passions, les besoins, l'éducation, les circonstances, tout semble, en effet, concourir pour pencher l'habitant des EtatsUnis vers la terre. La religion seule lui fait, de temps en temps, lever des regards passagers et distraits vers le ciel. Cessons donc de voir toutes les nations démocratiques sous la figure du peuple américain, et tâchons de les envisager enfin sous leurs propres traits.

Tristan, Flora: Pérégrinations d'une paria. Paris: Arthus Bertrand 1838, Bd. 1, S. S. 303: C'était chose neuve pour moi, enfant du XIXe siècle, arrivant de Paris, que la représentation d'un mystère joué sous le porche d'une église, en présence d'une foule immense de peuple ; mais le spectacle, plein d'enseignements, était la brutalité, les vêtements grossiers, les haillons de ce même peuple, dont l'extrême ignorance, la stupide superstition reportaient mon imagination au moyen-âge.

Bd. 2, S. 462: Je satisfis à tout, et le 15 juillet 1834, je quittai Lima à neuf heures du matin, pour me rendre au Callao. [...] Après le dîner, je fis transporter mes effets à bord du William-Rusthon et m'installai dans la chambre qu'avait occupée la señora Gamarra. Le lendemain, j'eus plusieurs visites de Lima; c'étaient les derniers adieux. Vers cinq heures, on leva l'ancre, tout le monde se retira; et je restai seule, entièrement seule, entre deux immensités, l'eau et le ciel.

Vian, Boris: L'écume des jours. Paris: 10/18 1977, S. 13: A chaque note, dit Colin, je fais correspondre un alcool, une liqueur ou un aromate. La pédale forte correspond à l'œuf battu et la pédale faible à la glace. Pour l'eau de Seltz, il faut un trille dans le registre aigu [...]. Lorsque l'on joue un air lent, un système de registre est mis en action, de façon que la dose ne soit pas augmentée - ce qui donnerait un cocktail trop abondant - mais la teneur en alcool. [...] Il n'y a qu'une chose gênante, dit Colin, c'est la pédale forte pour l'œuf battu. J'ai dû mettre un système d'enclenchement spécial, parce que lorsque l'on joue un morceau trop «hot», il tombe des morceaux d'omelette dans le cocktail, et c'est dur à avaler. [...] Chick se mit au piano. A la fin de l'air, une partie du panneau de devant se rabattit d'un coup sec et une rangée de verres apparut. Deux d'entre eux étaient pleins à ras bord d'une mixture appétissante.

\section{Villaverde, Cirilo: El guajiro. Cuadro de costumbres cubanas. La Habana} 1891, S. 74: Allí era donde, según el porte y el aire de cada cual, podía el curioso observador clasificar las clases o escalas en que se divide la sociedad de blancos 
que habita los campos de la isla. Conocería al administrador del ingenio por el tono de superioridad y mando con que habla y mira a los guajiros, lo mismo que por su chaqueta de paño negro o chupa de dril crudo, corbata alta y sombrero de jipijapa; conocería igualmente al mayoral de ingenio [...].

\section{Villaverde, Cirilo: El penitente. Novela de costumbres cubanas. La Habana:}

Editorial La Burgalesa 1925, S. 9: Yo, que no soy Walter Scott, ni conozco reyes ni reinas de quienes escribir cuentos ni historias, pero que tuve un abuelo cuentista y memorioso, tanto sin duda como el del célebre novelista escocés, me propongo referir tales como me los refirió, varios cuentos que si bien no versan sobre personajes coronados, vive Dios que merecen se pongan en letras de molde para entretenimiento y solaz del curioso lector.

Villaverde, Cirilo: Diario del Rancheador. Revista de la Biblioteca Nacional José Martí (La Habana) 15 (1973), S. 86 u. 109: Que seguramente habían hallado el rastro primero que nosotros, y fueron a dar con un palanque que estaba de nosotros más de media legua de distancia; seguimos dicho rastro, cuando sentimos el sonido de un trabucazo que tiraron a los perros; seguimos el rumbo por donde oímos el tiro, hasta que llegamos a encontrar una cueva al despuntar un paredón, y hallamos los perros malheridos de balas, ni hallar a nadie en dicha cueva; observamos para arriba como 4 cuadras, una gran ranchería, soltamos los demás perros, los seguimos todo este día; volvimos el siguiente, 15, a reconocer los ranchos y hallamos 16, y 7 que estaban haciendo de nuevo, calculamos que dichos ranchos podían contener de 50 a 60 negros; hallamos porción de lanzas que dejaron en la huida, varios chifles de pólvora fina, cuchillos de punta, con sinnúmero de piedras de fusil de las que venden en las tabernas, siete ú 8 mazos de estopas para tacos en diferentes ranchos, por lo que calculo que tienen 667 armas de fuego; encontramos también como 14 ó 15 serones de plátanos, carne de puerco y vaca, como 40 frazadas viejas, mucha ropa de hombre y mujer, porción de ollas y calderos, lo que juntamos y quemamos junto con la ranchería; las lanzas ó herrones las botamos donde no pudieran hallarlas y trajimos 10 para constancia, las que dejamos en casa de don Manuel Sotolongo en el Sud, partido de Santa Cruz. Desde el 15 a la fecha hemos gastado registrando los montes y velando en los cruceros, haciéndome cuentas que pudiéramos tener algún encuentro con ellos en vista de hallarse dispersos: efectivamente el 17 capturamos uno, y el 21 tuvimos un encuentro con 7, de los que capturamos dos, y se nos escaparon 5 , de los que se presentaron 2. [...] Viramos por la cordillera del S. y entre Rangel y el río de la Cruz, encontramos doce negros cimarrones que iban a buscar víveres a las llanuras de Limones y S. Bartolomé; les caímos y capturamos a los que resultaron ser 3 de D. Antonio de la Torre, dos de D. Francisco Rodríguez y el otro de 
don Antonio Salvableta, uno vecino de la Puerta de la Güira, otro de la nueva población de Limones y el otro de Sa Cruz; y dos que por no querer rendirse, se precipitaron de un paredón los cuales se mataron juntos con el mejor perro que me quedaba; interrogué a los vivos para saber dónde estaba la cuadrilla y cuál era su caudillo, me contestaron que éste era Yará antiquísimo capitán de cuadrilla y que no podían decirme más porque eran nuevos en el monte, y que habían sido conducidos por cuatro de los viejos, que dos de ellos eran los muertos y los otros dos se habían escapado; llegué a mi casa el 17, di parte a los S.S. Insp., demostré los comprobantes.

\section{Villaverde, Cirilo: Cecilia Valdés o La Loma del Ângel. La Habana: Editorial} Arte y Literatura 1977, S. 30: Lejos de inventar o de fingir caracteres y escenas fantasiosas e inverosímiles, he llevado el realismo, según lo entiendo, hasta el punto de presentar los principales personajes de la novela con todos sus pelos y señales, como vulgarmente se dice, vestidos con el traje que llevaron en vida, la mayor parte bajo su nombre y apellido verdaderos, hablando el mismo lenguaje que usaron en las escenas históricas en que figuraron [...].

S. 77: Narcisa entonces dio un grito de horror y trató de zafarse, pero la figura prieta le clavó las uñas en la garganta para que no gritara, y, cargando con ella, se subió a la torre del Ángel, que, según habrás reparado, no tiene cruz, y desde allí la arrojó en un pozo hondísimo que se abrió y volvió a cerrarse tragándosela en un instante. Pues esto es, hija, lo que le sucede a las niñas que no hacen caso de los consejos de sus mayores.

S. 212 f.: No me vengas con tus principios, tus fines ni tus leyes romanas. Digan ellas y ellos lo que gustes, la verdad es que existe mucha diferencia entre la conducta de tu padre y la de don Pedro Blanco. Este se halla allá, en la tierra de esos salvajes; él es quien los procura en trato, él es quien los atrapa por cambio o engaño, él es quien los apresa y remite, para su venta, en este país; de suerte que, si hay en ello algún delito o culpa, suyo será, en ningún caso de tu padre. Y, si bien se mira, lejos de hacer Gamboa nada malo o feo, hace un beneficio, una cosa digna de celebrarse, porque si recibe y vende, como consignatario, se entiende, hombres salvajes, es para bautizarlos y darles una religión que ciertamente no tienen en su tierra.

S. 487: No hay paridad ninguna en la fisonomía del país visto por ambos lados de las montañas. Por el del sur, la llanura con sus cafetales, dehesas y plantaciones de tabaco, continúa casi hasta el extremo de la Isla y es lo más ameno y risueño que puede imaginarse. Al contrario por el lado del norte, en el mismo paralelo se ofrece tan hondo, áspero y lúgubre a las miradas del viajero que cree pisar otra tierra y otro clima. 
Voltaire: Dictionnaire philosophique. Bd. IV (Euvres complètes de Voltaire, Bd. XX). Paris: Garnier Frères 1879, S. 185 f.: Telle est donc la condition humaine, que souhaiter la grandeur de son pays c'est souhaiter du mal à ses voisins. Celui qui voudrait que sa patrie ne fût jamais ni plus grande, ni plus petite, ni plus riche, ni plus pauvre, serait le citoyen de l'univers 